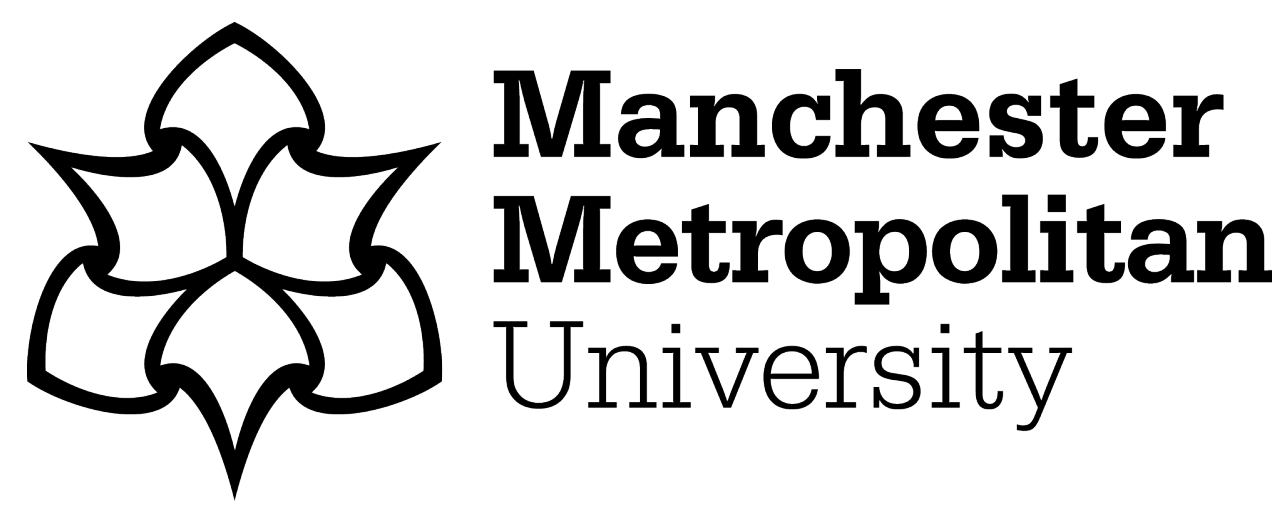

Giovanis, Eleftherios and Ozdamar, Oznur (2018) Productivity and Resource Misallocation: Evidence from Firms in in Middle East and North Africa (MENA) Region Countries. UNSPECIFIED. Economic Research Forum.

Downloaded from: https://e-space.mmu.ac.uk/621999/

Publisher: Economic Research Forum

Please cite the published version 

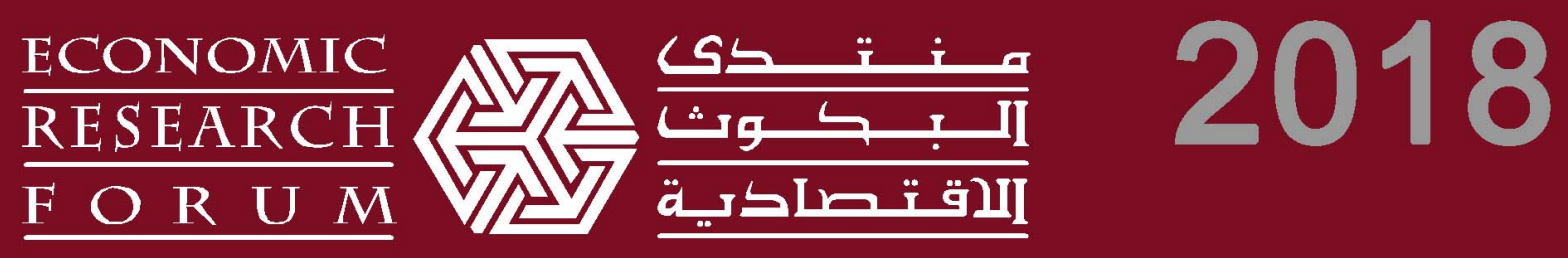

\section{working paper series}

PRODUCTIVITY AND RESOURCE MISALLOCATION: EVIDENCE FROM FIRMS IN MIDDLE EAST AND NORTH AFRICA (MENA) REGION COUNTRIES

Eleftherios Giovanis and Oznur Ozdamar

Working Paper No. 1266 


\title{
PRODUCTIVITY AND RESOURCE MISALLOCATION: EVIDENCE FROM FIRMS IN MIDDLE EAST AND NORTH AFRICA (MENA) REGION COUNTRIES ${ }^{1}$
}

\author{
Eleftherios Giovanis ${ }^{2}$ and Oznur Ozdamar ${ }^{3}$ \\ Working Paper No. 1266
}

December 2018

The authors are grateful to Dr. Jorge Luis Rodriguez Meza, who is Program Manager at the World Bank and they would like to thank him for his valuable comments, suggestions and constructive comments that greatly contributed to the improvement of the quality of this paper.

Send correspondence to:

Eleftherios Giovanis

Manchester Metropolitan University, Business School

L.giovanis@mmu.ac.uk

\footnotetext{
${ }^{1}$ We gratefully acknowledge financial support from the Economic Research Forum (ERF) under the project

"Structural Change, Resource Misallocation and Growth Dynamics in the MENA Region". The views expressed in this paper are those of the authors and do not necessarily represent those of the ERF.

${ }^{2}$ Manchester Metropolitan University, Business School, Department of Economics, Policy and International Business (EPIB), Manchester, United Kingdom, giovanis95@gmail.com.

${ }^{3}$ Adnan Menderes University, Faculty of Economics, Department of Econometrics, Aydin, Turkey, oznurozdamar@gmail.com, oznur.ozdamar@adu.edu.tr
} 
First published in 2018 by

The Economic Research Forum (ERF)

21 Al-Sad Al-Aaly Street

Dokki, Giza

Egypt

www.erf.org.eg

Copyright (C) The Economic Research Forum, 2018

All rights reserved. No part of this publication may be reproduced in any form or by any electronic or mechanical means, including information storage and retrieval systems, without permission in writing from the publisher.

The findings, interpretations and conclusions expressed in this publication are entirely those of the author(s) and should not be attributed to the Economic Research Forum, members of its Board of Trustees, or its donors. 


\begin{abstract}
Resource reallocation from low to high productivity firms can generate large aggregate productivity gains with further potential benefits to economic growth. This study examines the productivity and resource misallocation in a sample of countries in the Middle East and North Africa (MENA) region and Turkey. The analysis relies on data derived from the World Bank Enterprise Surveys over the period 2008-2016 of firms in Egypt, Turkey and Yemen. Furthermore, in the analysis we include various firm characteristics, and we explore major state-business relations (SBRs) and their association to resource misallocation. The results are mixed where in Egypt and Turkey female ownership and international quality are positively associated with productivity and allocation efficiency, while in all cases obstacles in SBRs present a negative and significant correlation with the firms' performance and productivity, reducing the allocation efficiency and increasing the dispersions on output and capital.
\end{abstract}

Keywords: Firm Level Data; Productivity; Resource Misallocation, State-Business Relations; World Bank Enterprise Surveys

JEL Classifications: D24, D61, D73, L25, O12, O43, O47

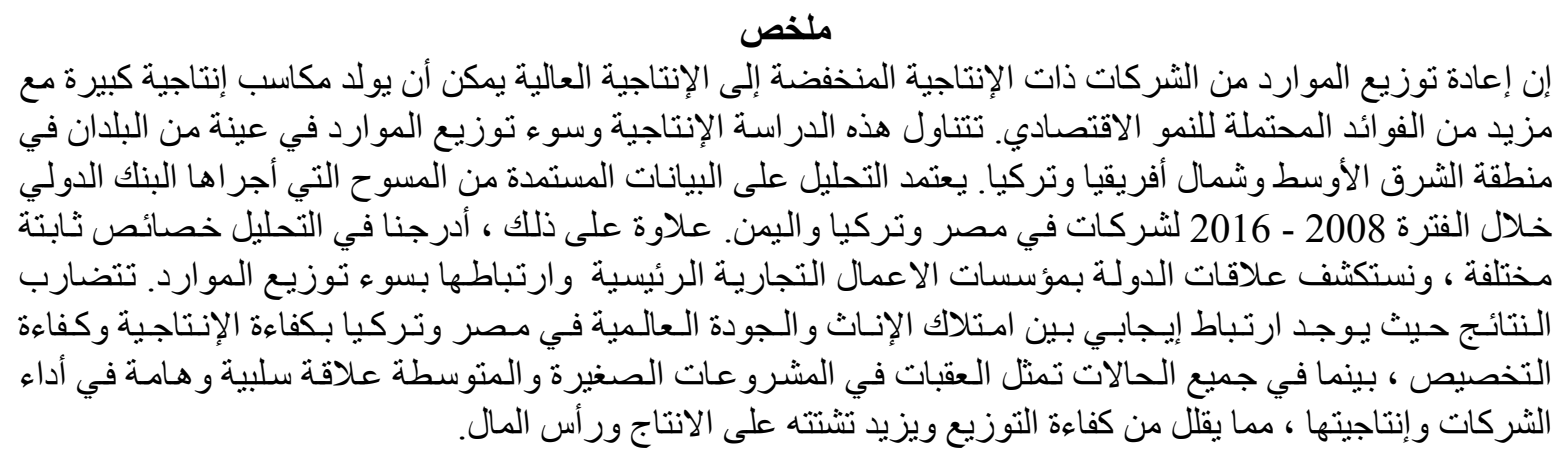




\section{Introduction}

The extensive economic literature documents the importance of total factor productivity (TFP) as a source and main driver of sustained economic growth and development. TFP greatly differs across countries, but also large differences are presented across firms that operate within same or very similar industries. Earlier studies try to give answers explaining those differences. One of the main explanations is that resource misallocation is a significant part interpreting these productivity differences, which can be due to the slow diffusion of best practice and management methods, technological diffusion and innovation generated by investment in research and development (R\&D). Policies encouraging investments in technology and innovation, upgrading of leaning and skills, but also policies that promote access to labour market for young and females are the focus of the recent research. However, the quality of SBRs can be also a major determinant of resource reallocation from low to high productivity firms. This is also the main aim of the study, to explore how the obstacles in SBRs may affect the TFP and the misallocation and reallocation of resources.

The analysis is based on the seminal work by Hsieh and Klenow (2009), who argue that the TFP of an industry depends not only on the TFP of the individual firms, but also on the resource allocation across the firms. In an economy characterised by low distortion, productive firms will have access to more resources, which is the capital and labour explored in this study, leading to an aggregate increase in the productivity of the sector and to a further overall economic growth. So, for the firms, operated to the same or to a narrowly defined industry, to be able to achieve the maximum allocation efficiency, they should be able to access the resources at this point where they attain the same marginal revenue products. Large dispersions in the marginal products within the same industry imply resource misallocation in the industry. Since corruption, political instability, tax rates and access to finance are the major factors of allowing a firm to have access to resources, it is crucial to explore these SBRs and their relationship to productivity. This includes favours for certain firms which are large or state-owned in terms of granting additional and unnecessary subsidies for political purposes, while the young and small, but more productive firms, may face limitations in terms of capital and finance and they could be "taxed" more from the state. Additionally, political instability and tax rates may significantly affect the firm performance. Many studies have shown how the corruption and regulation distort the resource allocation from their most efficient use and the most productive firms, especially in the lower-income economies, as is Egypt and Yemen explored in this study. However, as distortions may explain the resource misallocation other factors may also play a major role, which are described in more details in the next sections.

Thus, the main purpose of this study is to explore the resource misallocation that occurs, especially in distorted economies in this study where the labour and capital flow from the less productive to more productive firms is prevented. In the study by Hsieh and Klenow (2009) the potential total factor productivity (TFP) gains range between 30-50 per cent in China and 40-60 per cent in India if the resources were reallocated to equalise the marginal products to US levels. So far there is no study exploring systemically the economies of MENA region and Turkey, including also the role of the quality and obstacles in SBRs. The analysis will allow us to examine how much the productivity would be if the resources were allocated optimally across the firms. In particular, we will consider the 
marginal revenue product of capital (MRPK) and the marginal revenue product of labor (MRPL) across firms and we will explore in what extent of the misallocation dispersion in MRPK and MRPL is owned to rigidities and distortion of the economy, such as the obstacles faced by the firms. This study adds to the previous literature as is the first exercise exploring the potential TFP considering the obstacles in the SBRs business-state relations.

The organization of the paper is as follows. Section 2 discusses earlier studies. In section 3 we present the methodology followed in the empirical work and in section 4 we describe the data and sample used in the analysis. In section 5 we present the empirical results and in section 6 we discuss the main conclusions derived from the study.

\section{Literature Review}

Numerous studies have explored the resource misallocation in advanced and developed economies, but also in developing economies, including countries in Latin America, India, China and other Asian economies. However, there is no study so far exploring systematically the resource misallocation in the economies of the MENA region and in Turkey, as well as, the role of additional factors, such as the quality of SBRs.

Earlier studies that examined the implications of the misallocation on productivity can be split in two categories; those studies that adopt the direct approach and others that follow the indirect approach (Chuah et al., 2018). Studies following the direct approach obtain a direct measure of factors or explore specific regulations that cause input misallocation. The study by Hopenhayn and Rogerson (1993) shows that firing taxes distort the labour allocation across firms, resulting to a loss of TFP at about 2 percent and in output loss of 5 percent. Similarly, Lagos (2006) studied the implications of labour market regulation, which include employment protection and unemployment insurance. Other studies explored the impact of reductions on trade tariffs on firm productivity and whether large changes lead to resource misallocation (Lileeva and Trefler, 2010; Epifani and Gancia, 2011; Eslava et al., 2013).

The indirect approach differs and relies on the fact that in some cases it is rather difficult to measure a source of misallocation or there is a very specialized condition. Therefore, the indirect approach attempts to identify the extent of misallocation without identifying the underlying source of misallocation. However, even though the indirect approach sounds to be intuitively powerful, it relies on specific assumptions and about the misallocation measurements, which are associated with two main limitations. First, the wedges do not always necessary reflect distortion, but may be a result of production function misspecification. Second, given that wedges are estimated using actual data, may also reflect measurement errors in the data (Chuah et al., 2018).

Numerous studies explored the resource misallocation around the globe following the estimation approach by Hsieh and Klenow (2009). These include the study by Busso et al., (2013) for Latin American countries, the paper by Nguyen et al. (2016) for Turkey, and the study by Cirera et al. (2017) for African countries. Bartelsman et al. (2013) use firm-level data for five industrial economies and three transition economies of Central and Eastern Europe and they developed a model of heterogeneous 
firms to explain the variation in misallocation across countries by adjustment distortions that in turn lead to aggregate productivity performance differences. They found a significant variation in the within-industry misallocation across countries, which allocation is measured by the covariance between size and productivity. A similar study by Asker et al. (2014) explore the adjustment costs associated with dynamic production inputs and in what extent lead to capital misallocation within industries and countries. They found that a very large proportion of the variation in the dispersion of the MRPK across countries and industries is explained by the volatility in productivity. Other studies also explored the extent of misallocation, but their analysis is limited to developed countries and there is no evidence so far from a systemic analysis in the economies of MENA region. Furthermore, we can argue that the distortions and frictions in developing economies and the countries of the MENA region can be potentially significantly larger. Restuccia and Rogerson (2008) found that the misallocation can have larger effects on productivity if high productivity producers face systematic constraints.

A number of studies has also marked the importance and the role of the credit constraints in creating distortions resulting to capital misallocation across firms (Caballero et al., 2008; Caggese and Cunat, 2013; Brandt et al, 2013; Midrigan and Xu, 2014; Gopinath et al, 2015). This obstacle is a factor that is explored in this study, including also corruption, supply for electricity, tax rates and political instability. Hsieh et al (2013) argue that a misallocation of labour in the US since 1960 is observed coming from the reduction in race and gender discrimination. Furthermore, the labour misallocation can be a result of policies that affect the size of firm distribution (Guner et al., 2008). If misallocation explains the TFP differences across firms and countries, then the reallocation of production is a key driver of gains in productivity. Thus, we will additionally explore the distortions driven by institutional obstacles. The analysis is based also on the framework by Oberfield (2013) who explored the impact of the Chilean crisis in 1982.

\section{Methodology}

In this section we describe the quantification of the effect of misallocation on TFP, using the accounting framework proposed by Hsieh and Klenow (2009) and hereafter we call it HK model. We assume that output $Y$ is produced in each country using a Cobb-Douglas production technology.

$Y=\prod_{s=1}^{s} Y_{s}^{\theta_{s}}$

Where $\theta_{s}$ is the value added of sector $s$ and

$$
\sum_{s=1}^{s} \theta_{s}=1
$$

The total final output in the economy $Y$, is a Dixit-Stiglitz aggregator of the output produced by each sector $Y$. The sector's output $Y_{s}$ is the aggregate individual firms' output $Y_{s i}$ using the Constant Elasticity of Substitution (CES) technology as:

$$
Y_{s}=\left(\sum_{i=1}^{M_{s}} Y_{s i}^{\frac{\sigma-1}{\sigma}}\right)^{\frac{\sigma}{\sigma-1}}
$$


Where $\sigma$ denotes the elasticity of substitution between varieties and $Y s i$ is the differentiated product by firm $i$ in sector $s$. We assume the standard Cobb-Douglas production function for the production of each firm

$$
Y_{s i}=A_{s i} L_{s i}^{1-a_{s}} K_{s i}^{a_{s}}
$$

$A$ indicates the specific productivity of firm $i$ in sector $s$; $L$ and $K$ denote respectively the firm's labour and capital and $a_{s}$ is the industry-specific capital share. We should notice that in this framework we consider firms in the same defined sector expressed by the 4-digit International Standard Industrial Classification (ISIC). Following Hsieh and Klenow (2009) and other studies (León-Ledesma, 2016; Cirera et al., 2017; Chuah et al., 2018) the firm maximizes the profit as:

$\pi_{s i}=\max _{K, L}\left[\left(1-\tau_{Y s i}\right) P_{s i} Y_{s i}-w_{s i} L_{s i}-\left(1-\tau_{K s i}\right) R K_{s i}\right]$

Where $P_{s i} Y_{s i}$ is the firm's value added, calculates as the firm's sales-revenue minus the cost of intermediate inputs and $w_{s i}$ and $R$ are respectively the cost of one unit of labour and capital. We should notice that there are two distortions affecting firms. One that has an impact on the firm output $\tau_{Y s i}$ and the second that affects the relative factor inputs $\tau_{K s i \text {. }}$ Since it is impossible to identify separately and disentangle the distortion effects on capital and labour, earlier studies suggest to impose the distortion on capital, which actually in this case we interpret the distortion that affect the relative price of labour and capital. As we assume that these distortions are firm specific and due to heterogeneity will not affect all the firms at the same way, creating differences in the capital-labour ratios among the firms is a good approach to measure and investigate the misallocation. In equation (5) $P_{s i} Y_{s i}$ is the value added for firm $i$, while $w_{s i}$ and $R$ denote the wage rates and the rental price of capital respectively. $\tau_{K s i}$ denotes the firm-specific capital distortion that increases the cost of capital relative to labour and it implies that

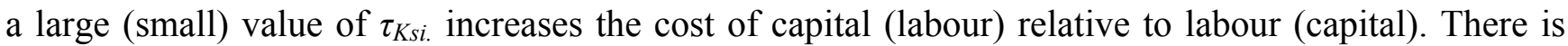
also a set of factors that potentially cause distortions, such as the labour market and trade regulations, credit and finance market imperfection among others, and these distortions differ across the firms which is expressed by $\tau_{Y s i}$. Following Hsieh and Klenow (2009) we differentiate for two productivity measures; the TFPQ, which captures the "physical productivity" and the TFPR which captures the "revenue productivity".

$$
\begin{aligned}
& \operatorname{TFPQ}_{s i}=\frac{Y_{s i}}{L_{s i}^{1-a} K_{s i}^{a}} \\
& \operatorname{TFPR}_{s i}=\frac{P_{s i} Y_{s i}}{L_{s i}^{1-a} K_{s i}^{a}}
\end{aligned}
$$

Relations (6)-(7) shows us that TFPR should not vary across firms within each sector in the absence of distortions. This means that more labour and capital should be allocated to the firms with higher TFPQ up to the point their higher output results in a lower price expressed by $P_{s i}$ equalizing also the TFPR across the firms. Thus, any dispersions of TFPR imply distortion within the sector and firms whose TFPR is higher than the sector averages will face the effects of distortions. On the other hand, we would expect TFPR to vary because the productivity levels vary across firms. Using the revenue data we can re-write the $T F P Q_{s i}$ as: 
$T F P Q_{s i}=A_{s i}=\frac{\left(P_{s i} Y_{s i}\right)^{\frac{\sigma}{\sigma-1}}}{\left(w L_{s i}\right)^{1-a_{s}} K_{s i}^{a_{s}}}$

Taking the first order condition for the profit maximisation we have:

$$
\begin{aligned}
& \operatorname{MRPK}_{s i}=\frac{R\left(1+\tau_{K s i}\right)}{\left(1-\tau_{y s i}\right)} \\
& M R P L_{s i}=\frac{w_{s i}}{\left(1-\tau_{y s i}\right)}
\end{aligned}
$$

Substitution of (9)-(10) in the production function we find the optimal price for each variety that is a markup over marginal costs.

$$
P_{s i}=\frac{\sigma}{\sigma-1}\left(\frac{R}{a_{s}}\right)^{a_{s}}\left(\frac{w}{1-a_{s}}\right)^{1-a_{s}}\left(\frac{1+\tau_{K s i}}{A_{s i}\left(1+\tau_{y s i}\right)}\right)^{1-a_{s}}
$$

We observe that in the absence of distortions the firm's relative shares of output and labour would be only a function of $\mathrm{A}_{\mathrm{i}}$; however, the pricing rule (11) shows that the output quantity produced and the labour quantity demanded are proportional to their individual TFPs and the distortions they face. The output and capital wedges which measure distortions are defined respectively by (12) and (13).

$$
\begin{aligned}
1-\tau_{Y s i} & =\frac{\sigma}{\sigma-1} \frac{w_{s i} L_{s i}}{\left(1-a_{s}\right) P_{s i} Y_{s i}} \\
1+\tau_{K s i} & =\frac{a_{s}}{1-a_{s}} \frac{w_{s i} L_{s i}}{R K_{s i}}
\end{aligned}
$$

Firm $i$ 's labour cost is represented by , and PsiYsi represents, as before, the firm's value added. Taking equation (13) we define the labour-capital ratio in the less distorted environment as:

$1+\tau_{K s i} \frac{1-a_{s}}{a_{s}}=\frac{w_{s i} L_{s i}}{R K_{s i}}$

Relation (14) tells us that if firm i's actual labour-capital ratio is higher than the less distorted labourcapital ratio, this implies that firm $i$ is probably facing constraints in access to capital relative to hiring labour. Therefore, that firm uses less capital level than the optimal one and this is indicated by a positive capital wedge. Following Hsieh and Klenow (2009) we assume that without distortions, TFPRsi is proportional to the product of the marginal revenue product of capital and labour as:

$$
T_{F P R_{s i}} \propto\left(M R P K_{s i}\right)^{a_{s}}\left(M R P L_{s i}\right)^{1-a_{s}}
$$

We re-write (15) considering the previous relations and we have:

$$
T F P R_{s i}=\frac{\sigma}{\sigma-1}\left(\frac{R}{a_{s}}\right)^{a_{s}}\left(\frac{w}{1-a_{s}}\right)^{1-a_{s}} \frac{\left(1+\tau_{K s i}\right)^{a_{s}}}{1-\tau_{Y s i}}
$$

According to (16) in the absence of distortions, where the output and capital wedges are zero $\left(\tau_{K s i}=0\right.$ and $\left.\tau_{Y s i}=0\right), T F P R$ will be the same for all the firms within a sector. Using (16) when a firm presents a higher $\tau_{K s i}$ and/or higher $\tau_{Y s i}$ then it will also have a higher TFPR. 
The industry level $\overline{T F P R}$ is:

$\overline{T F P R}=\left(\frac{\sigma}{\sigma-1} \frac{R}{a_{s} \sum_{i=1}^{M_{s}}\left(\frac{1-\tau_{Y s i}}{1+\tau_{K s i}}\right)\left(\frac{P_{s i} Y_{s i}}{P_{s} Y_{s}}\right)}\right)^{a_{s}}\left(\frac{w}{1-a_{s} \sum_{i=1}^{M_{s}}\left(1-\tau_{Y s i}\right)\left(\frac{P_{s i} Y_{s i}}{P_{s} Y_{s}}\right)}\right)^{1-a_{s}}$

In the absence of distortions, where the capital and output wedges are zero, the right hand of (17) will be equal with the left hand, which means that $T F P R_{S}$ are equalized for all firms $i$. This implies that aggregate $T F P$ is maximized when there are no distortions in $T F P R_{i}$ and this gives us the optimal level of TFP in the absence of distortions. The estimation of the firms' physical productivity, defined by TFP $Q_{s i}$, based on the CES technology aggregator was presented in (8): The efficient industry's productivity level, where all the marginal products are equalized, is:

$$
\overline{A_{s}}=\left(\sum_{i=1}^{M_{s}} A_{s i}^{\sigma-1}\right)^{\frac{1}{\sigma-1}}
$$

From equations (8), (16)-(18), we can calculate the ratio of the actual TFP in the economy to the efficient level of TFP as:

$$
\frac{Y}{Y^{*}}=\prod_{s=1}^{S}\left[\sum_{i=1}^{M_{s}}\left[\frac{A_{s i}}{\overline{A_{s}}} \frac{\overline{\operatorname{TFPR}_{s}}}{\operatorname{TFPR}_{s i}}\right]^{\sigma-1}\right]^{\frac{\theta_{s}}{\sigma-1}}
$$

Where $Y^{*}$ denotes the efficient output and $\theta s$ is defined as before. One crucial parameter is the $\sigma$ which denotes the elasticity of substitution across firms within the sectors and the choice of its value is important for the estimation of the allocation efficiency. Following, Hsieh and Klenow (2009) and other studies (Oberfield, 2013; Cirera et al., 2017) we choose the elasticity of substitution, $\sigma=3$ which is taken from US firms. The justification of using this value relies on the assumption that US firms operate in an environment of minimal distortions. Even though may not be so realistic, we argue that in countries, such as Turkey and Egypt, explored in this study, obstacles in state-business relations are common, including corruption, political instability and access to finance and credit. We should notice that we followed the approach by Cirera et al. (2017) who tested the results using a value of $\sigma=5$, as also we tried with values equal at 2 and 4 and our results remain very similar, but we do not present them. Also we should notice that the Cobb-Douglas we assume is not innocuous, if the elasticity of substitution between labour and capital is different from one, then the dispersion of the MPK and thus the gains from reallocation can substantially change (León Ledesma et al., 2010; León-Ledesma, 2016). Following Oberfield (2013) and Hsieh and Klenow (2009) we measure the total misallocation as the ratio between the output level one would observe if the production factors were efficiently allocated and the actual aggregate production.

$$
M=\frac{Y^{*}}{Y}=\prod_{s=1}^{S}\left(\frac{Y_{s}^{*}}{Y_{s}}\right)^{\theta_{s}}
$$

The measure (20) can be separated into two parts. The first one measures the within-industry misallocation and is derived by taking the ratio between the maximum output achieved by production 
factors' allocation across firms within each industry $Y^{*}, w$ and the actual production. The second measures is the between-industry misallocation and is defined as the ratio between the output $Y^{*}$ and $Y^{*}, w$. The within-industry and between-industry measures of allocation efficiency are presented by (21) and (22).

$$
\begin{aligned}
& M_{W}=\frac{Y}{Y^{*}} \\
& M_{B}=\frac{Y^{*}}{Y^{* *}}
\end{aligned}
$$

Where $Y^{*}$ and $Y^{* *}$ are defined respectively as the total quantity of capital and labour within the industry and across the economy (Hsieh and Klenow, 2009; Oberfield, 2013). In (21) MW measures the contribution of the within-industry allocation efficiency to the aggregate output and is based on the study by Oberfield (2013). In particular, when this measure reaches 1 the capital and labour are optimally allocated across the firms within each industry. Relation (22) shows similarly, the additional contribution to output of the allocation efficiency between industries between-industry, so we consider the total output of firms in each industry. The general regression applied has the following form:

$$
Y_{s, j, t}=\beta_{0}+\beta_{1} \mathbf{S B R}_{s, j, t}+\beta^{\prime} \mathbf{X}_{s, j, t}+\mu_{s}+l_{j}+\theta_{t}+\varepsilon_{s, j, t}
$$

$Y$ denotes the outcomes of interest, which is the standard deviation of output and capital wedges defined respectively as $S D\left(\log \left(\tau_{y}\right)\right)$ and $S D\left(\log \left(\tau_{k}\right)\right)$, and the within and between industry misallocation indices expressed by (22)-(23). The regression is estimated at industry $s$, in district-governorate $j$ and time $t$. The SBRs is the main variable of interest which denotes the severity of obstacles in certain responses, such as tax rates, political instability and access to finance among others. $\mathbf{X}$ is a vector of standard control variables which are reported in table 1 . Set $\mu_{k}$ controls for fixed-industry effects, set $l_{j}$

\begin{tabular}{|c|c|c|c|}
\hline Variable & Description & Variable & Description \\
\hline $\begin{array}{c}\text { Misallocation } \\
\text { efficiency } \\
\text { measures }\end{array}$ & $\begin{array}{l}\text { The outcomes refer to the variable described } \\
\text { in the methodology section, including the } \\
\text { standard deviation of capital and output wedge } \\
\text { and the within-industry and between-industry } \\
\text { misallocation efficiency measures. }\end{array}$ & $\begin{array}{c}\text { Foreign } \\
\text { ownership }\end{array}$ & $\begin{array}{l}\text { A dummy taking value } 1 \text { if firm has at } \\
\text { least } 10 \% \text { foreign ownership }\end{array}$ \\
\hline $\log ($ Size $)$ & $\begin{array}{l}\text { logarithm of total number of full-time } \\
\text { permanent employment in year } t \text {. }\end{array}$ & Exporter & $\begin{array}{l}\text { A dummy taking value } 1 \text { if firm exports } \\
\text { at least } 10 \% \text { of its annual sales }\end{array}$ \\
\hline Log(Age) & $\begin{array}{l}\text { logarithm of the number of years that the firm } \\
\text { has been in operation }\end{array}$ & $\begin{array}{l}\text { Legal } \\
\text { status }\end{array}$ & $\begin{array}{l}\text { A categorical variable indicating the legal } \\
\text { status of the firm } 1 \text { for Shareholding } \\
\text { company with shares traded; } 2 \text { for } \\
\text { Shareholding company with shares non- } \\
\text { traded; } 3 \text { for Sole proprietorship; } 4 \text { for } \\
\text { Partnership and } 5 \text { for Limited Partnership }\end{array}$ \\
\hline $\begin{array}{c}\text { Female } \\
\text { ownership }\end{array}$ & $\begin{array}{l}\text { A dummy taking value } 1 \text { if there is female } \\
\text { participation in ownership }\end{array}$ & Region & Sampling region \\
\hline $\begin{array}{c}\text { Part of a } \\
\text { Larger Firm }\end{array}$ & $\begin{array}{l}\text { A dummy taking value } 1 \text { if the establishment } \\
\text { is part of a larger firm? }\end{array}$ & SBRs & $\begin{array}{l}\text { State-Business Relations indicating the } \\
\text { obstacle e.g. of access to finance and } \\
\text { credit, electricity, corruption, political } \\
\text { instability, tax rates and others. It takes }\end{array}$ \\
\hline
\end{tabular}
denotes the district-governorate fixed effects, and $\theta_{t}$ is the time-fixed effects.

\section{Table 1. Variables and Descriptions}


value 1 if the obstacle is major or very severe.

\begin{tabular}{clll}
\hline $\begin{array}{c}\text { Quality } \\
\text { certification }\end{array}$ & $\begin{array}{l}\text { A dummy taking value 1 if the establishment } \\
\text { has an internationally- recognized quality } \\
\text { certification? }\end{array}$ & ISIC & $\begin{array}{l}\text { 4-digit International Standard Industrial } \\
\text { Classification code that applies to the } \\
\text { main operations of the firms and location }\end{array}$ \\
\hline Capital & $\begin{array}{l}\text { This variable is used to calculate the outcomes } \\
\text { of the regression analysis and this is expressed } \\
\text { as replacement value of assets }\end{array}$ & Labour & $\begin{array}{l}\text { This variable is used to calculate the } \\
\text { outcomes of the regression analysis and is } \\
\text { expressed as the total labour cost } \\
\text { including wages and salaries. }\end{array}$ \\
\hline
\end{tabular}

About the SBRs we aim to explore the most important obstacles and not all the possible constraints. In table 2 we report the proportions about how respondents evaluate the obstacles and which ones are the biggest obstacles for the operation of the establishment. A possible way of exploring the impact of SBBs would be their inclusion in one regression. Nevertheless, we avoid following this approach for the main reason of multicollinearity which lead to biased estimates and furthermore, we will not disentangle separately their effects. Another choice would be to investigate the relationship between the outcomes of interest and the aggregate SBRs, creating an index using non-parametric analysis, such as principal components analysis. However, we are interested on the individual evaluation of the most important SBRs and not the overall impact of all obstacles. Thus, establishing an aggregated index measuring the total effect, but without disentangling their individual effect is out of the current's study scope. For this reason we limit our analysis to the three major obstacles, while the regressions for the obstacles with very low response ranging between 0.8-5, show an insignificant coefficient. According to table 2 we will explore the following obstacles as proxies of the SBRs in Egypt: political instability, access to finance and electricity. In Panel B we report the respective proportions for the Turkish firms. We observe that access to finance and political instability are two of the main obstacles similar to the Egyptian firms. However, we will explore two additional SBRs, the tax rates and practices from firms in the informal sector. In Panel $\mathrm{C}$ we conclude that similarly with Egypt and Turkey the major obstacle in SBRs and business environment is the political instability, followed by electricity and corruption aggregated almost at 68 percent of the 15 obstacles reported in the table.

Table 2. Descriptive Statistics for the Biggest Obstacle Affecting the Operation of the Establishment

\begin{tabular}{cccc}
\hline Variables & Percentage & Panel A: Egypt & Variables \\
Access to finance & 12.33 & Inadequately educated workforce & 3.26 \\
Access to land & 1.42 & Labour regulations & 3.84 \\
Business licensing and & 5.17 & Political instability & 39.77 \\
permits & & & 3.65 \\
Corruption & 5.32 & Practices of competitors in the informal sector & 1.61 \\
Courts & 0.82 & Tax administration & 6.38 \\
Crime, theft and disorder & 2.57 & Tax rates & 1.16 \\
Customs and trade regulations & 2.53 & Transportation & \\
Electricity & 10.17 & & Percentage \\
Variables & \multicolumn{3}{c}{6.92} \\
Access to finance & 17.93 & Panel B: Turkey & 1.65 \\
Access to land & 0.96 & Inadequately educated workforce & 14.81 \\
Business licensing and & 2.29 & Labour regulations \\
permits & & Political instability &
\end{tabular}




\begin{tabular}{cccc} 
Corruption & 3.48 & Practices of competitors in the informal sector & 17.10 \\
Courts & 0.64 & Tax administration & 1.42 \\
Crime, theft and disorder & 0.83 & Tax rates & 22.24 \\
Customs and trade regulations & 1.65 & Transportation & 2.12 \\
Electricity & 5.96 & & Percentage \\
Variables & Percentage & Panel C: Yemen & 3.55 \\
Access to finance & 5.64 & Variables & 0.49 \\
Access to land & 4.04 & Labour regulations & 25.25 \\
Business licensing and & 0.86 & Political instability & 3.06 \\
permits & & & 2.57 \\
Corruption & 21.08 & Practices of competitors in the informal sector & 4.04 \\
Courts & 1.72 & Tax administration & 0.74 \\
Crime, theft and disorder & 2.94 & Tax rates & \\
Customs and trade regulations & 2.08 & Transportation & \\
Electricity & 21.94 & & \\
\hline
\end{tabular}

Regarding the rest of the variables the two factors that have mainly explored in earlier studies are the firm size and age. Diaz and Sanchez (2008) argue that due to increase in managerial complexity an inverse relationship between productivity and firm size can be expected. On the contrary, large firm have more access to the local, regional and in some cases in the international market and they use more advanced technology, so a positive association between productivity and size can be also presented (Lundvall and Battesse, 2000; Biesebroeck, 2005). Along with firm size and age other studies use similar variables to explore the probability of firm's exit (Lawless, 2014; Aga and Francis, 2017)

The foreign ownership is also used in previous studies to explore whether the foreign-owned present lower probabilities of risk to exit, because of better access to information and market and due to possible favours in terms of tax treatment or whether face problems related to lack of knowledge of the local market and culture (Bernard and Sjöholm, 2003; Baldwin and Yan 2011; Gelübcke and Wagner, 2012; Aga and Francis, 2017). While these studies explore the probabilities of firm's exit, still we consider that are related to our empirical analysis because it may have an impact on firm's performance or it may affect the resource misallocation due to "special" treatments. In line with this we include also a dummy indicating the following: exporter which is defined as if at least the 10 percent of the annual sales is exported and whether the firm is accredited with an international quality certification. We assume that firms that export are more likely to have access to a wider information at the international markets and other advantageous positions that affect their performance. Another variable of interest is the gender ownership and whether at least one of the owners is female. We include this information into our regression analysis, following earlier studies suggesting that women show a lower risk preference investing in activities associated with lower risk compared to their men counterparts (Croson and Gneezy, 2009; Faccio et al., 2016). Since the previous literature refers to risk and firm's exiting rates, we argue that this variable is related also to the productivity and resource misallocation. We also include as another control variable in our analysis the legal status of the firm, indicating whether the firm is classified as a partnership, limited partnership and whether is a shareholding company with shares traded among others. This can be related to our topic, as the legal status of the firm is a possible confounder of SBRs and resource misallocation. For instance, workplaces classified as firms with limited liability, is found to present higher growth compared to firms with different legal 
structure (Harhoff et al., 1998). Another control variable is the sampling region or the firm's location which is defined as district-governorate in Egypt and as a Nomenclature of Territorial Units for Statistics (NUTS) at level 1-region in Turkey. Also we control for the firm's sector, which is defined as manufacturing or services. These controls intend to capture unobserved heterogeneity and timeinvariant conditions at the sector and area level affecting particular firms. Also these allow us to capture for location characteristics, the quality and skills of the workers available in a certain area and also preferences for the firms' products and services which may affect their performance and productivity.

While the use of the variables included into the regression analysis have been justified, still can be endogenous. For instance, firm size may affect the productivity, but also more productive firms may expand the size of the firm. Also more productive firms may apply for an international quality control certification or to increase the proportions for their sales to exports. However, we aim to explore some of the most important possible factors of productivity and misallocation, which are available in the ES data and have not been examined so far.

In particular, we recognize three main sources of endogeneity of SBRs including the self-statement and perception about the obstacles, the omitted variables bias, and reverse causality (Beck et al., 2005; Carlin et al., 2006). The major issue is the possible degree of the reverse causality, where the direction of the effect can go from SBRs to productivity or resource misallocation, while on the other hand firms with higher productivity rates may also over-report the effectiveness of SBRs. Furthermore, the direction and the sign of the bias depend on certain firms, especially for the large ones that are able to bribe and have a "special" treatment from the government. For this reason, and due to the fact that we find difficult to use proper and suitable instruments that can be convincing, we interpret the regression results as plain correlations.

\section{Data}

The analysis relies on data derived from the Enterprise Survey provided by the World Bank ${ }^{4}$. The period examined differs between the countries and ranges between 2008-2016. Enterprise surveys cover more than 130,000 firms in 125 countries; however, our aim is to explore the resource misallocation and employment growth in a selected sample of countries in the MENA region. These surveys cover various topics and include many characteristics of the firm and they focus also on information that shape the business environment, including factors that may accommodate of constrain firms and they can play an important role on whether country will grow and prosper. The World Bank ES allow us to follow a comparative analysis across firms, sectors, countries and years. The surveys contain information on subjective and objective factors and characteristics of the business environment. More specifically, the subjective questions we employ here refer to evaluations about the severity of obstacles in the SBRs. The respondents are asked to rank from a list of 15 components about their impact on the business environment, measured on a scale between 1 and 5 , where 5 indicates a severe

\footnotetext{
${ }^{4}$ Enterprise Surveys (http://www.enterprisesurveys.org), The World Bank.
} 
obstacle and value 1 shows no obstacle. Overall, Enterprise Surveys are very useful because they provide also a rich set of variables and other firm characteristics.

We limit our analysis to the global surveys conducted by World Bank in order to use representative samples. In particular, we use the 2008 and 2013 cross section surveys in Turkey and the respective surveys in Egypt for the years 2013 and 2016, while for Yemen we use the panel survey in years 2010 and 2013. While for Yemen we have a full-panel data, for Turkey and Egypt, following the strategy of previous studies, we make use of the full cross section surveys, including both panel and non-panel component. This approach provide us with the possibility to follow a comparative analysis of the trends across the economies explored (Aga et al., 2015; Aga and Francis, 2017). Furthermore, following these studies we account for sampling weight in both descriptive statistics and in the regression analysis. The strata for the ES is based on the firm size, business sector and geographical location-region within a country. For the capital we consider the replacement costs of machinery and equipment which corresponds on the market value of the capital. In order to prevent the effects of extreme values in the capital, we trimmed the upper and lower 1 percent of the sample.

In table 3 we report the summary statistics using sampling weights for the main control variables. The main purpose of table 3 is to highlight the similarities and differences across the firms between the three economies explored. Regarding firm size and age we observe that the averages are very close to all economies, where the average number of employees is 115 and the average age is 21 in Egypt, 138 employees and 24 years in Turkey, while the respective value in Yemen are 17 and 19. Thus, while the average age is similar across countries the average firm size is significantly lower in Yemen.

There are significant also differences among the countries explored, regarding the rest of the variables. In particular, while the female ownership in Egypt and Yemen is only 6.8 percent, the percentage in Turkey reaches the 30 percent. This shows that female entrepreneurship is more common in Turkey, while women in Egypt and Yemen have rather less opportunities to establish or take part to business activities. Thus, it would be useful to explore whether the female ownership has significant relationship with resource misallocation, besides its possible endogeneity, as it may shed helpful insights about the labour force and ownership structure and the potential gender role in the economic growth. The 6 and 4.3 percent of the Egyptian and Turkish firms respectively in our sample is classified as of foreign ownership, according to the definition of table 1, while the respective percentage in Yemen is only 1.3. Regarding the international quality certification only the 4.4 and 10 percent of the sample has been accredited with a relevant certification respectively in Yemen and Egypt compared with the 31.5 percent in Turkey. Also large differences are observed in the firms that are defined as exporters which consist only of 4.9 in Yemen and 7.6 percent in Egypt compared to 20 percent in Turkey. These statistics illustrate the openness of the firms which is significantly higher in Turkey. Thus, beyond their possible endogeneity it is worthwhile to explore the relationship among those variables and the outcomes used in the empirical work. 
Table 3. Descriptive statistics for the control variables

\begin{tabular}{|c|c|c|c|c|c|c|c|}
\hline \multicolumn{8}{|c|}{ Panel A: Egypt } \\
\hline Variable & Average & $\begin{array}{c}\text { Linearized } \\
\text { Standard } \\
\text { Error }\end{array}$ & $\begin{array}{c}\text { No. } \\
\text { observations }\end{array}$ & Variable & Average & $\begin{array}{c}\text { Standard } \\
\text { Deviation }\end{array}$ & $\begin{array}{c}\text { No. } \\
\text { observations }\end{array}$ \\
\hline $\begin{array}{c}\text { Log of Firm } \\
\text { Size }\end{array}$ & 2.740 & 0.0356 & 4,616 & $\begin{array}{c}\text { Quality } \\
\text { certification }\end{array}$ & 0.104 & 0.0115 & 4,626 \\
\hline $\begin{array}{c}\text { Log of Firm } \\
\text { Age }\end{array}$ & 2.503 & 0.0358 & 4,639 & $\begin{array}{c}\text { Foreign } \\
\text { ownership }\end{array}$ & 6.098 & 0.6567 & 4,676 \\
\hline $\begin{array}{c}\text { Female } \\
\text { ownership }\end{array}$ & 0.068 & 0.0107 & 3,941 & Exporter & 7.600 & 1.0171 & 4,663 \\
\hline $\begin{array}{c}\text { Part of Larger } \\
\text { Firm }\end{array}$ & 0.190 & 0.0149 & 3,498 & & & & \\
\hline \multicolumn{8}{|c|}{ Panel B: Turkey } \\
\hline Variable & Average & $\begin{array}{c}\text { Linearized } \\
\text { Standard } \\
\text { Error }\end{array}$ & $\begin{array}{c}\text { No. } \\
\text { observations }\end{array}$ & Variable & Average & $\begin{array}{l}\text { Standard } \\
\text { Deviation }\end{array}$ & $\begin{array}{c}\text { No. } \\
\text { observations }\end{array}$ \\
\hline $\begin{array}{c}\text { Log of Firm } \\
\text { Size }\end{array}$ & 2.859 & 0.0545 & 2,459 & $\begin{array}{c}\text { Quality } \\
\text { certification }\end{array}$ & 0.316 & 0.0330 & 2,420 \\
\hline $\begin{array}{c}\text { Log of Firm } \\
\text { Age }\end{array}$ & 2.551 & 0.0485 & 2,437 & $\begin{array}{c}\text { Foreign } \\
\text { ownership } \\
(\%)\end{array}$ & 4.365 & 0.4913 & 2,470 \\
\hline $\begin{array}{c}\text { Female } \\
\text { ownership }\end{array}$ & 0.301 & 0.0327 & 2,478 & Exporter $(\%)$ & 20.337 & 2.2640 & 2,462 \\
\hline $\begin{array}{l}\text { Part of Larger } \\
\text { Firm }\end{array}$ & 0.087 & 0.0115 & 2,496 & & & & \\
\hline \multicolumn{8}{|c|}{ Panel C: Yemen } \\
\hline Variable & Average & $\begin{array}{c}\text { Linearized } \\
\text { Standard } \\
\text { Error }\end{array}$ & $\begin{array}{c}\text { No. } \\
\text { observations }\end{array}$ & Variable & Average & $\begin{array}{c}\text { Linearized } \\
\text { Standard } \\
\text { Error }\end{array}$ & $\begin{array}{c}\text { No. } \\
\text { observations }\end{array}$ \\
\hline $\begin{array}{c}\text { Log of Firm } \\
\text { Size }\end{array}$ & 2.190 & 0.0471 & 816 & $\begin{array}{c}\text { Quality } \\
\text { certification }\end{array}$ & 0.0440 & 0.0096 & 819 \\
\hline $\begin{array}{c}\text { Log of Firm } \\
\text { Age }\end{array}$ & 2.424 & 0.0500 & 808 & $\begin{array}{c}\text { Foreign } \\
\text { ownership } \\
(\%)\end{array}$ & 1.2677 & 0.4809 & 821 \\
\hline $\begin{array}{c}\text { Female } \\
\text { ownership }\end{array}$ & 0.0667 & 0.0141 & 824 & Exporter $(\%)$ & 4.8923 & 2.8286 & 826 \\
\hline $\begin{array}{l}\text { Part of Larger } \\
\text { Firm }\end{array}$ & 0.3580 & 0.0402 & 830 & & & & \\
\hline
\end{tabular}

\section{Empirical Results}

In figure 1 we present the log deviation of the aggregate production value added and the TFP in the three countries we explore. The deviation is based on the first year of the sample period for each country which varies; for Egypt is 2013, for Turkey is 2008, and for Yemen is 2010. In figure 2 we present the log deviation of capital and labour from the base year of every country as in the figure 1 . The value added is defined as before, while the measured TFP is based on the Cobb-Dougles estimates using the Levinsohn-Petrin (LP) method. The common characteristic among the economies explored is the real value added is higher than the measured TFP, except for Yemen, but both measures present a significant reduction between 2010-2013. On the contrary, the value added was slightly increased in Egypt, while the measured TFP remained stable. In Turkey, we observe an inverse situation, where the value added is decreased, and the measured TFP increased. 
A similar situation is observed in figure 2 where we show the log deviations of the capital and labour, which reflects the movements in figure 1. In particular, in Egypt, both employment and capital presented a small increase, while in Yemen a large drop in both factors of production is recorded. On the contrary, an increase in capital is observed in Turkish firms, while the employment remained stable similar to the case of Egypt.

Figure 1. Aggregate Production Value Added TFP and capital-labour

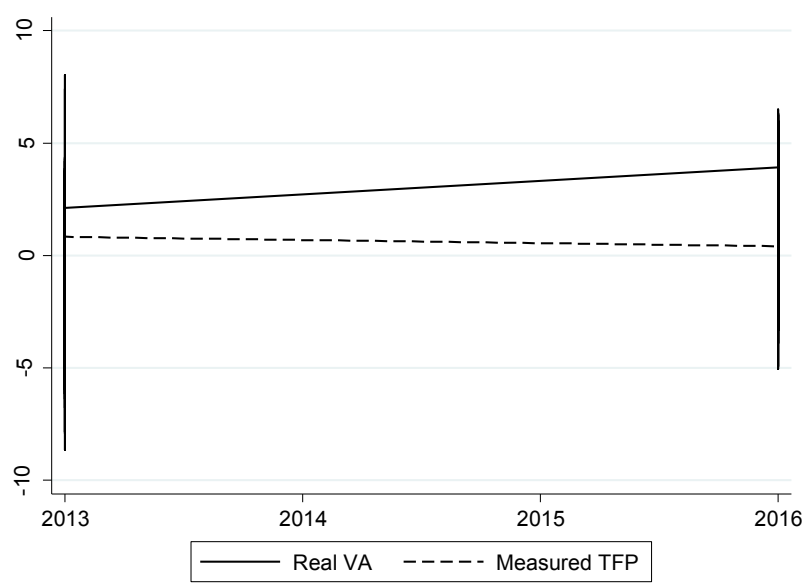

(a) Egypt

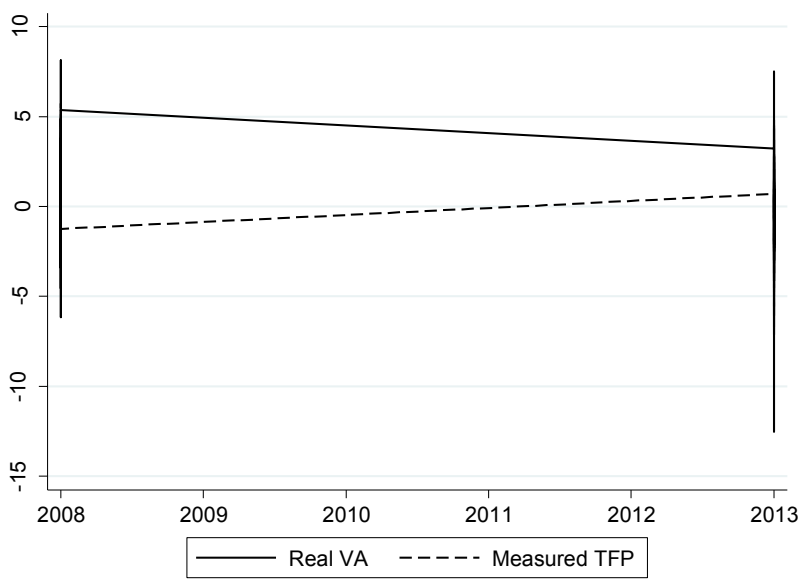

(b) Turkey

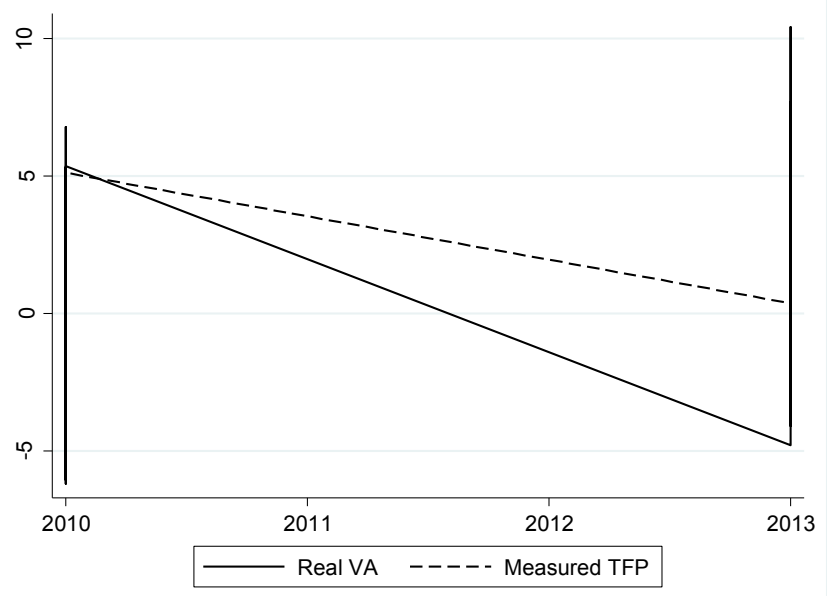

(c) Yemen 
Figure 2. Aggregate Production Capital and Labour

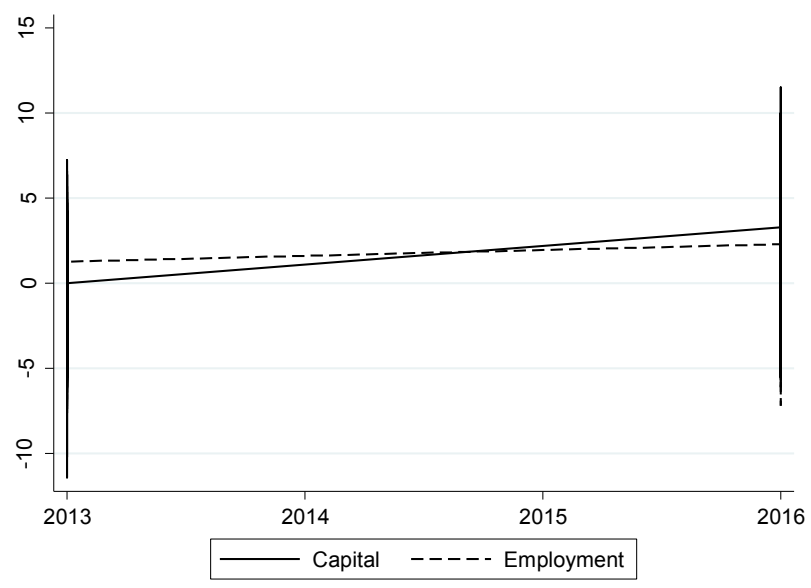

(a) Egypt

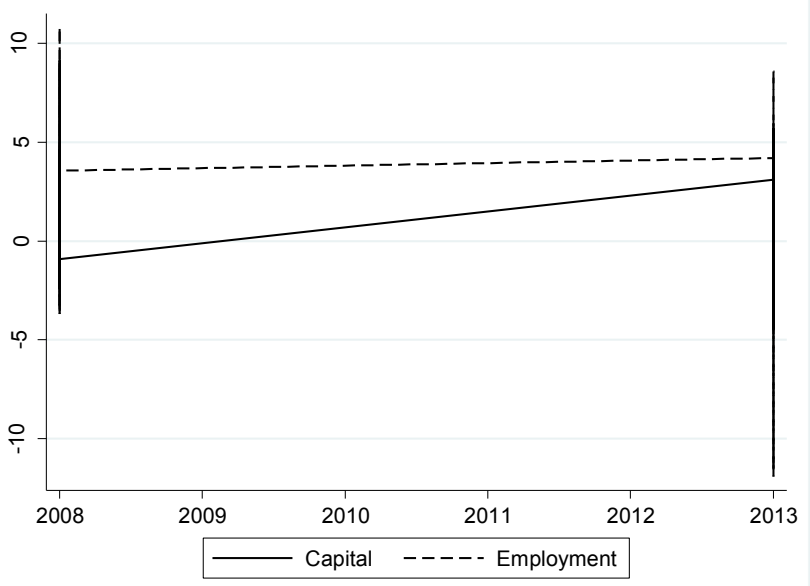

(b) Turkey

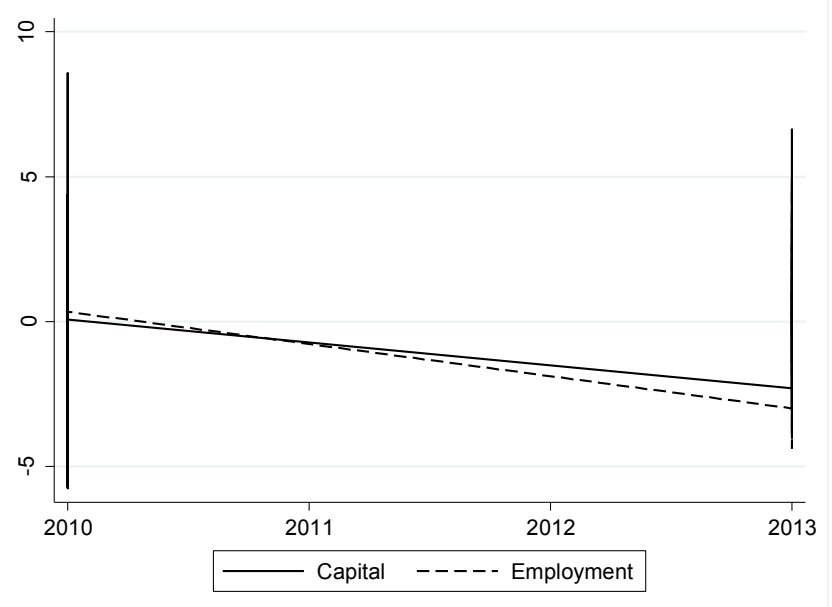

(c) Yemen

Following the methodology by Hsieh and Klenow (2009) and Oberfield (2013) we then estimate and present the dispersion of labour and capital wedges, the scale wedges, and within-industry and between-industry allocation efficiency. Even though the aim of the Oberfield's study is to explore the impact of the Chilean crisis in 1982, our aim is to show the resource misallocation since the starting point of the data-surveys. Figure 3 shows for each year a measure of dispersion of capital and labour wedges which is expressed by the log deviations between the $90^{\text {th }}$ and $10^{\text {th }}$ percentiles and between the $75^{\text {th }}$ and $25^{\text {th }}$ percentiles of the respective distribution among the firms. According to the methodology described in the previous section, the capital and labour wedges for firm $i$ are defined respectively as:

$$
\begin{aligned}
& C W=\frac{P_{i} Y_{i} / K_{i}}{P_{i}^{*} Y_{i}^{*} / K_{i}^{*}} \\
& C L=\frac{P_{i} Y_{i} / L_{i}}{P_{i}^{*} Y_{i}^{*} / L_{i}^{*}}
\end{aligned}
$$

Where the asterisk in (24)-(25), denotes the labour, capital and value added in the efficient allocation. The solid lines show the capital wedges and the dash lines represent the labour wedges. The average 
wedges across firms equals the average productivity gain from reallocating the input by one unit in the optimal direction. If the wedge is higher the larger the input misallocation will be because the larger the potential gains from reallocating resources. In Egypt we observe a significant increase in both capital dispersion measures, which is the ratios of 90-10 and 75-25 percentiles, and stability in the labour wedges across the time explored. Exception is the labour dispersion of ratio 90-10 which was lightly decreased. In Yemen we observe a similar situation, but a significant larger increase in the capital and labour with 90-10 ratio is illustrated. In Turkey the situation is quite different, as both capital and labour wedges ratios remained rather stable across the period 2008-2013, except from labour wedge and the ratio 90-10 which marked a slight decrease in 2013. Overall, we see that the allocation efficiency is not improved, as in some cases there were slight increases in the wedges. Also, the main driver of the resource misallocation is found on capital and these dispersions emerge as more important than labour dispersions in explaining the potential gains in value-added and productivity gains. This can vary by the firm size, age and the sector. While we limit our analysis to allocation efficiency and the role of SBRs, it would be equally worthy to investigate also the relationship between capital-labour dispersion and the SBRs and firm characteristics. Nevertheless, this can be explored in future studies.

\section{Figure 3. Dispersion of capital and labour wedges}

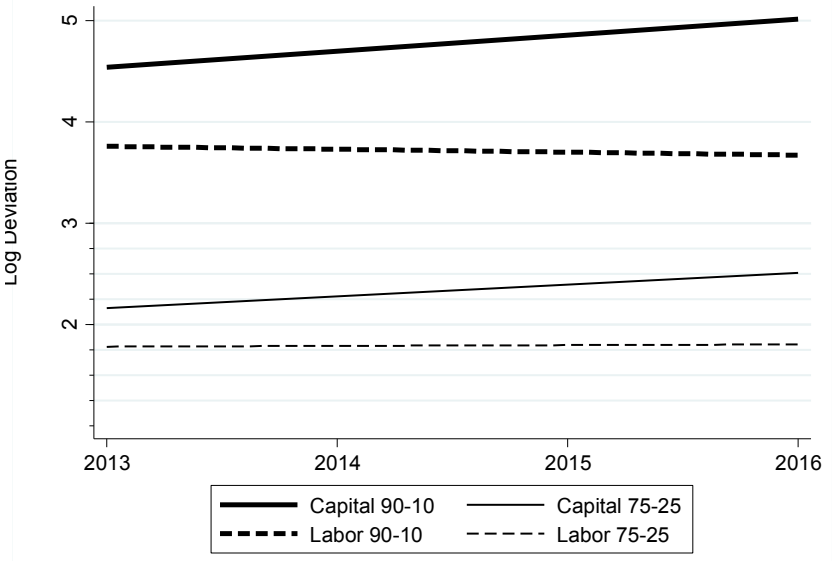

(a) Egypt

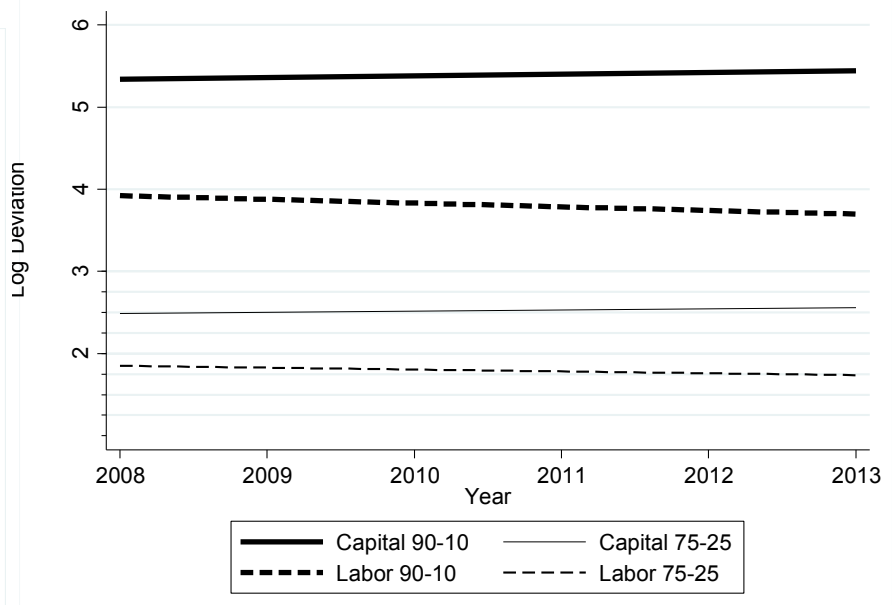

(b) Turkey

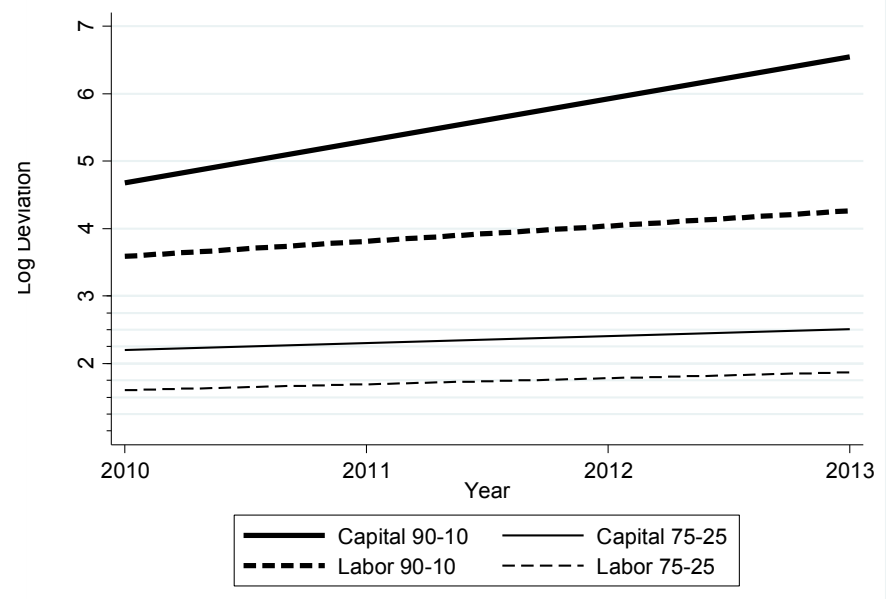

(c) Yemen 
In figure 4 we present the scale wedges for different years in each country depending on the data and year the surveys were conducted and we show how these scale wedges vary with firm size and how this is changed across time. In all cases the graphs are based on the quantiles of the first year presented on the graph. The scale wedge for firm $i$ and considering again the efficient allocation of $K^{*}, L^{*}$ and $Y^{*}$ it will be:

$$
S W=\frac{P_{i} Y_{i} /\left(K_{i}^{a_{i}} L_{i}^{1-a_{i}}\right)}{P_{i}^{*} Y^{*}{ }_{i} / K^{* a_{i}} L_{i}^{* 1-a_{i}}}
$$

In Panel (a) of figure 4 we present the scale wedge for Egypt in 2013 and 2016, in panel (b) we show the case of Turkey for the years 2008 and 2013 and in panel (c) we illustrate the scale wedges for Yemen in period 2010-2013. We have divided the firms into groups of 20. In all cases we observe that larger firms on the average have higher scale wedges indicating that firm size is negatively associated with the allocation efficiency. Furthermore, small firms also present high mean log of standard deviation of scale wedges in the sample of the firms in Egypt and Turkey, while in Yemen small firms seems to present higher allocation efficiency up to a quantile of 0.6. Also, we observe that the mediumsized firms in Turkey and Egypt present also lower scale wedges located between the 0.4-0.6 quantiles. Thus, we conclude that up to some level of size the efficiency is maximized and then it drops. So, another argument of considering the quadratic terms of firm size in the regressions analysis is to capture the behaviour illustrated in figure 4. The same applies also for firm age, where we will test whether there is a quadratic relationship with the efficiency. Thus, in figure 4 we explore the role of the firm size and how it generates wedges in the allocation of resources across firms as a source of misallocation. Therefore, as we have discussed the results in figure 3 , it would be also interesting to investigate the association between SBRs and other characteristics with the scale wedges. Furthermore, figure 4 does not provide any additional valuable information for the following reasons. First, in the absence of policy evaluation there is no much added value, since we cannot establish the effects of SBRs and other factors of interest on resource misallocation. Second, another important factor in determining the effect of dispersions is the assumption about the curvature in the firm level production function for which it seem there is no general consensus. For instance, the study by Hsieh and Klenow (2009) employs a value of $a=0.5$, while other studies take a value of $a=0.85$ (eg. Restuccia and Rogerson, 2008). However, in this study we consider first a production function and we attempt to estimate the capital share value $a$. Since, earlier studies mainly explore developed economies, or developing economies that show a high productivity progress over the last years, our study is limited to lower-middle income countries. Thus, the capital share ranges between 0.3-0.5 in the countries we explore. Furthermore, we propose for future research to extract the wedges using a second step where the wedges will be estimated controlling for the main factor of interest, such as the SBRs and particular domains, including for example constraints about the access to finance and credit, tax rates and labour and trade regulations among others. 
Figure 4. Scale wedges

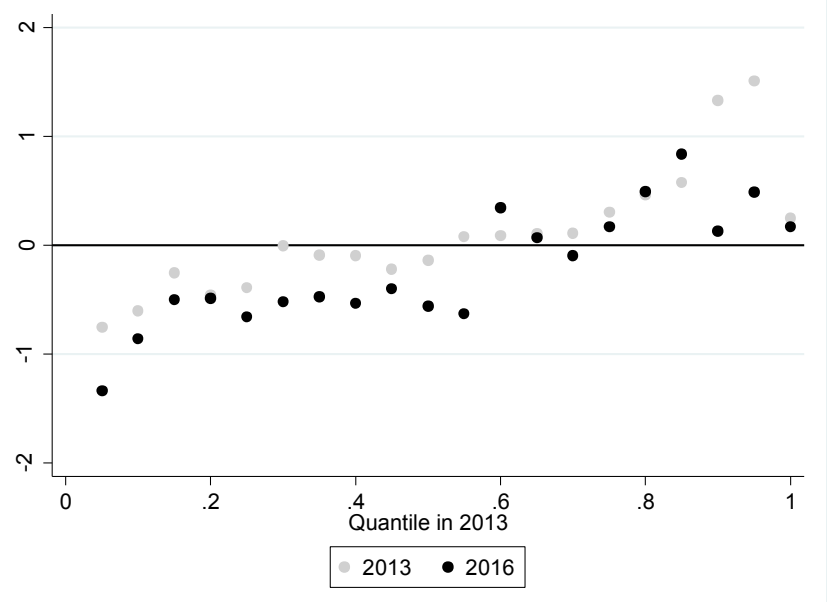

(a) Egypt

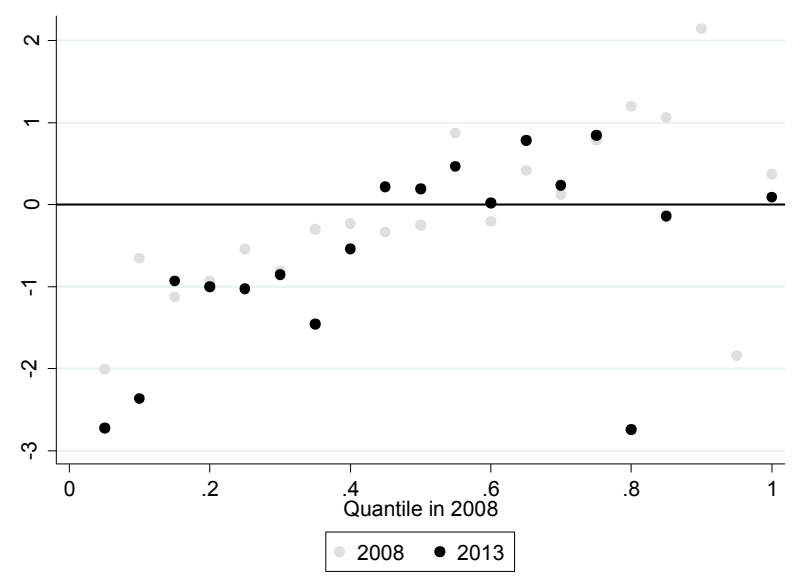

(b) Turkey

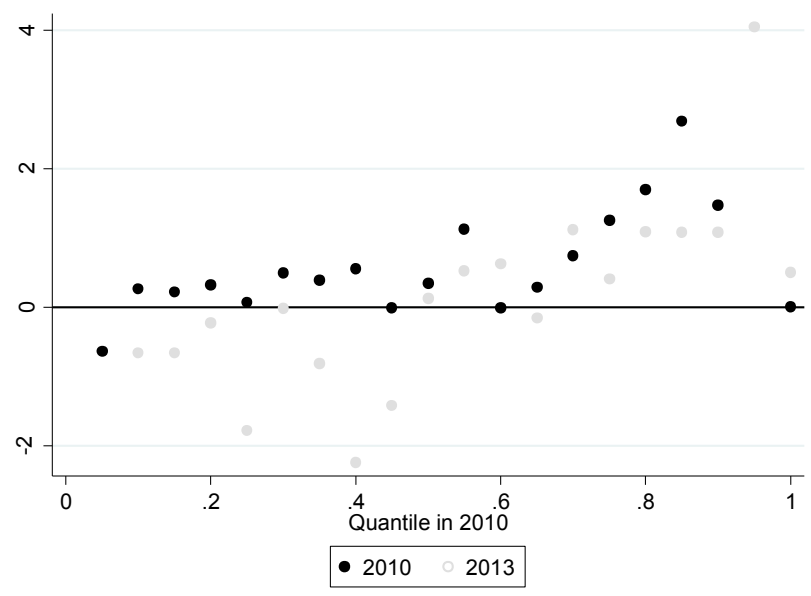

(c) Yemen

Even though the findings so far provide a small role of the within-industry misallocation in specific periods and especially after 2007, which may be associated with the global economic recession of 2007-2008, we turn our analysis to the structural decomposition. In figure 5 we present the allocation efficiency and specifically the efficiency within and between industries, as well as, considering both within and between industry. In each graph and country there are three lines; the solid line shows the between-industry efficiency efficiency, the dashed-line shows the within-industry efficiency efficiency and the dotted-line shows both within and between-industry. The within-industry is the actual output divided by the output that could be attained if the resources within each industry were optimally allocated. Similarly, the between-industry line shows the ratio of the output that could be attained if the resources were optimally allocated within each industry and across all the plants respectively. The third line (both within and between-industry) shows the actual output divided by the output that could be achieved if the resources were optimally allocated across the firms. In all cases the output is away from the efficient optimum. It is remarkable that the allocation efficiency based on all three measures is higher in Egypt, where the average value of $M W$ and $M B$ is respectively 0.3033 and 0.5095 , over the period we examine, while the respective values in Turkey are 0.1694 and 0.3579 according to panel A 
of table 4. However, we should notice two factors that show Turkish economy presented a higher growth of allocation efficiency. First, the $M W$ value remained almost stable in Egypt between 2013 and 2016, while the respective value in Turkey was almost doubled. The same applies also for the betweenindustry measure $M B$, while the allocation efficiency in both within and between industries increased significantly from 0.0037 to 0.1351 . These results, along with the illustrations in figure 5 , show that the allocation efficiency was relatively higher in Turkish firms compared with the Egyptian workplaces. Second and equally important is the period we examine. While in Turkey we use the period 2008 and 2013, according to the data available, the period we employ in the case of Egypt is 2013 and 2016. More specifically, we use 2008 as the first year of our analysis in Turkish firms, which was exactly the year of the great recession and this had a huge impact on the economies around the globe including Turkey. Furthermore, as we have shown also in the descriptive statistics, the Turkish firms are more "open" as they are more likely to be a part of another firm, to export more and more likely to have foreign ownership. This indicates that the Turkish firms could be more exposed on the effects of the great recession of 2007-2008 and it took at least a couple of years for the countries to recover from the economic shocks. Also, we do not include in our analysis the year of 2016, as we do in Egypt, and this do not allow for a robust comparative analysis. However, we observe that all the measures remained stable during this period and there was no significant change. The within-industry allocation efficiency presented a small increase, while the between-industry was slightly decreased.

In Yemen we observe that the main driver of allocation efficiency is the within industry misallocation, which was very slightly increased in 2013, while the between-industry allocation efficiency was increased in 2013 compared to 2010. On the contrary, we observe that the main driver of the overall allocation efficiency is noted in the between-industry for both Egypt and Turkey, recording an increase. The within-industry allocation efficiency in Turkey was significantly increased, while in Egypt was increased only by 0.0087 , and in particular, from 0.3000 in 2013 to 0.3087 in 2016.

In panel $\mathrm{B}$ of table 4 we report the average values of the $M W$ derived from the study by Hsieh and Klenow (2009), while the values for $M B$ and Mboth are unavailable, as the authors have not estimated them. We observe that the values found for China and India are significantly lower than the countries explored in this study. However, the results are not easy to be compared due to the different time frames, as the allocation efficiency for India refers to 1994 and for China in 2005. As it was expected the allocation efficiency in USA firms is substantially higher, even though a reduction was recorded in 1997. Also, we should notice that our sample is small, as well as, we have shown that Turkey's allocation efficiency has substantially been improved in 2013 compared to 2008, while for Egypt and Yemen have been almost stagnated. 
Figure 5. Allocation Efficiency Within-Industry and Between-Industry

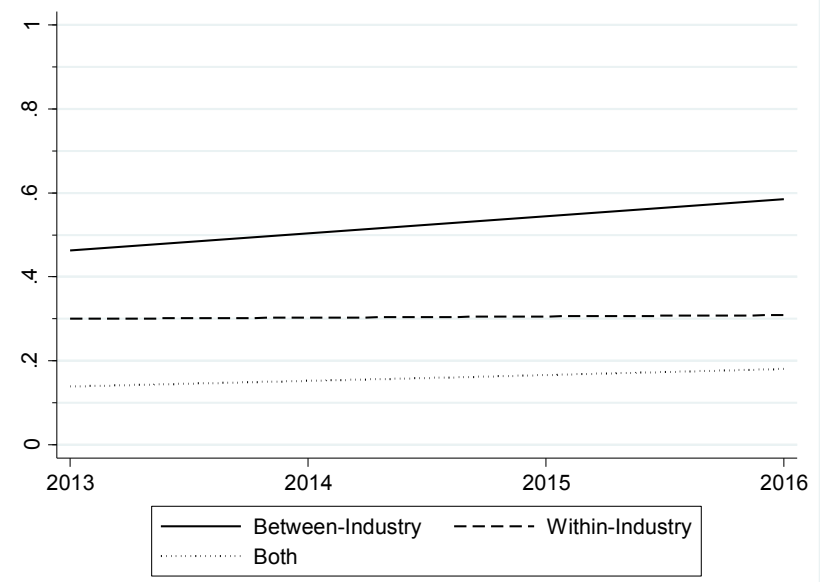

(a) Egypt

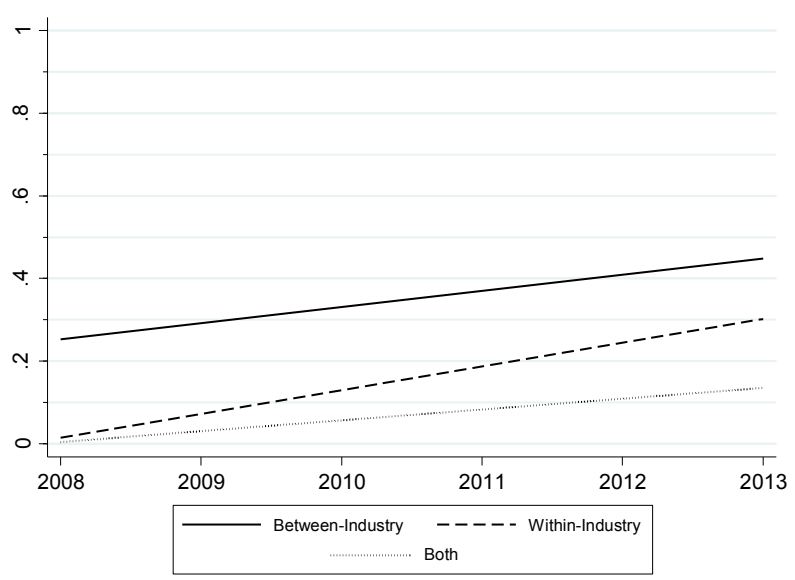

(b) Turkey

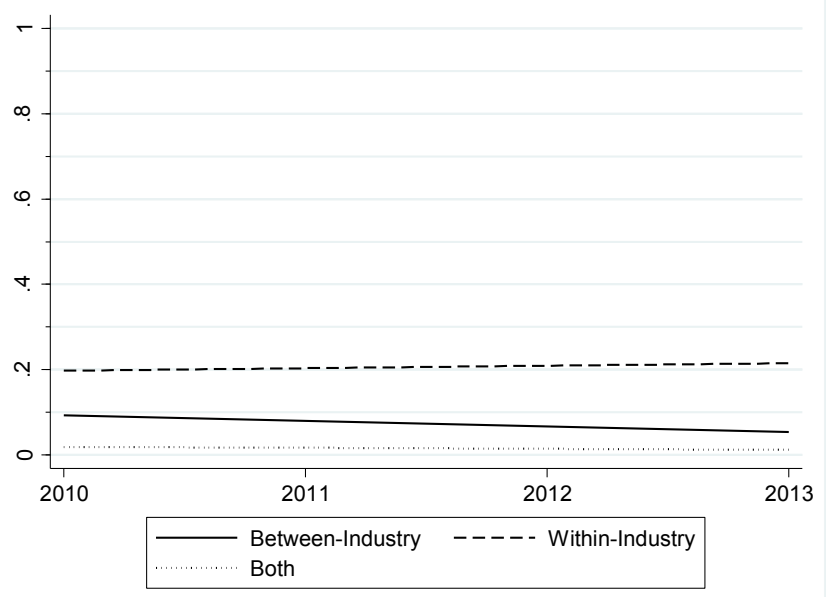

(c) Yemen

Table 4. Average Values of Within-Industry and Between-Industry Allocation Efficiency Measures

\begin{tabular}{cccc} 
& MW & Panel A: Study's estimates & \\
Egypt 2013-2016 & 0.3033 & MB & Mboth \\
Egypt 2013 & 0.3000 & 0.5095 & 0.1548 \\
Egypt 2016 & 0.3087 & 0.4623 & 0.1387 \\
Turkey 2008-2013 & 0.1694 & 0.5848 & 0.1805 \\
Turkey 2008 & 0.0148 & 0.4397 & 0.0745 \\
Turkey 2013 & 0.3018 & 0.2513 & 0.0037 \\
Yemen 2010-2013 & 0.2048 & 0.4447 & 0.1351 \\
Yemen 2010 & 0.1973 & 0.0751 & 0.0154 \\
Yemen 2013 & 0.2149 & 0.0932 & 0.0184 \\
\hline
\end{tabular}

Panel B: Hsieh and Klenow

(2009) 


\begin{tabular}{llll} 
China 2001 & 0.042 & n.a & n.a \\
China 2005 & 0.134 & n.a & n.a \\
India 1991 & 0.020 & n.a & n.a \\
India 1994 & 0.125 & n.a & n.a \\
USA 1987 & 0.693 & n.a & n.a \\
USA 1997 & 0.571 & n.a & n.a \\
\hline
\end{tabular}

In tables 5-7 we report the regression results in the economies we explore. As we mentioned earlier we examine only the major constraints in SBRs we presented in table 2. In table 5 we report the results for Egypt considering the obstacles in access to finance; political instability and electricity, where the main factor of interest takes the value 1 if the obstacle in a certain SBR characteristic is severe or major. In the first two columns, the dependent variables of main interest include the dispersion on output and capital, measured as the standard deviation of their logarithmic values, while in columns (3) -(4) we estimate the regressions for the within-industry (MW) and the between-industry (MB) allocation efficiency measures. It is remarkable that the political instability presents the lowest adverse correlation with allocation efficiency, and quality on electricity seems to be the major constraint on SBRs. These results may provide valuable insights to public authorities and policy makers that frequent and long electrical outages may create significant problems in productivity. Furthermore, large firms may be better equipped and thus better protected against those outages and the poor quality on electricity supply. Even though we saw that increases in firm size are associated with better levels of allocation efficiency, this does not necessarily imply that small firms are not efficient. In particular, large firms can also have better access to finance and public authorities, where small firms may reduce their efficiency because have no access for various reasons, and no support from the government regarding the electricity supply.

Similarly, in Turkey we observe that the two main obstacles in SBRs is access to finance and political instability, as we have seen in the case of Egypt, while the tax rates is the third major obstacle to the business environment as we have illustrated in table 2. In particular, obstacles related with the access to finance increase the dispersion on output, while significantly reduce the allocation efficiency. On the other hand, the effect of the political instability is higher. The last obstacle explored is the tax rates which reduce both $M W$ and $M B$ allocation efficiency and increases the dispersions on output. In Yemen we observe that political instability and electricity are also major obstacles to SBRs, with corruption being the third major constraint. We conclude that poor quality on the specific SBRs significantly reduce the allocation efficiency, but also increase the dispersions on output and capital, except for electricity, whose estimated coefficient is insignificant. Overall, the correlation between corruption and allocation efficiency is the highest, followed by electricity and political instability. In particular, we see that the SBRs reduce the within and between industry allocation efficiency by $0.07-0.2$ percent in Egypt. In Turkey tax rates and constraints to finance reduce efficiency by 2 percent and political instability by 4 percent. In Yemen, electricity and political instability contribute to resource misallocation by 1.3 percent and corruption by roughly 2 percent. 
The findings so far are consistent with earlier studies that explored the impact of electricity, financial markets and political instability on firm performance, such as sales, and employment growth, but not on allocation efficiency as this study attempts to examine. These studies suggest that unreliable supply of electricity, expressed by numerous, frequent and long electrical outages have a significant negative effect on firm growth. For instance, a report published by World Bank in 2008 (World Bank, 2008) shows that unreliable, expensive and in some cases unavailable electricity constitutes a major barrier for Kenyan firms. Similarly, the study by Lea and Hanmer (2009) finds that electricity and unreliable power supply is one of the major constraints in the business environment in Malawi, and one of the main barriers of investments in industries with high demand for power. Lemma et al. (2016) using a survey of 813 firms in Tanzania found that unreliable and poor quality of electricity is a major obstacle to firm operations costing to firms around 15 per cent of their annual sales.

Earlier studies have also highlighted the importance of access to finance and credit and its importance to the firm growth, where small-medium firms have less access to formal sources of external finance compared to large firms. This is explained by the poor structure of the capital markets, characterizing these economies, but also is due corruption that commonly large and privileged firms are the favoured isolating the small firms that are in more need of financing their operations (Beck and Demirguc-Kunt, 2006). As it is expected these obstacles significantly reduce the capability of small-medium firms to have access to finance and capital. The issue becomes even more crucial especially when these constraints isolate those firms are more in need, such as the start-ups, which can be productive and become even more productive in the near future, but poor SBRs may limit or even stop their potential promising operations.

Political instability is another major constraint on SBRs and thus on allocation efficiency, especially on exporting firms that could be more affected, especially during periods of political turmoil, including the countries we explore in this study (Collier and Duponchel, 2013). Also smaller firms may tend to perceive political instability as a bigger obstacle to their operations and business environment, compared to large firms, because they have less access to finance and capital markets, and also fewer resources to survive during periods of turmoil. Furthermore, as we have shown, firm size is related to lower allocation efficiency, but these firms have a significantly larger bargaining power, relative to small firms, to influence policy makers and obtain preferential treatments (Schiffer and Weder, 2001).

Tax rates can be also important to allocation efficiency, and a major obstacle to the business environment, especially to small firms having low access to capital and financial markets and due to these higher rates will be unable to hire high-skilled employees and high-technology capital reducing in this way their productivity. Tax rates can be an important factor of the firm performance, as tax related compliance costs will add significantly to the tax burden that firms face and these can be particularly high for the small-medium enterprises, and also the young firms (Venkatesh and Slemrod, 2002; Lignier and Evans, 2012; Coolidge, 2012). A high tax corporate rate implies a high compliance burden diverting resource from productive activities, such as investments on physical capital and productivity enhancing innovations, increasing the costs of input factors without creating additional output, or creating a low quality output, and thus firm productivity and allocation efficiency decline. 
For the remained factors of resource misallocation, we report the estimated coefficients using only one SBR obstacle, because the results remain almost identical when we include the remained obstacles in SBRs and thus, we decided to not report them as these do not add any extra information. For the firm age and size we included also a quadratic term, to capture possible non-linearities, as increases in the firm size may have an inverse effect on the outcome. In other words, it may take time or a firm needs to reach a certain level of size to improve productivity. On the contrary, it can be the case that older and larger firms becomes less productive or due to other factors, such as the SBRs are "subsidized" more, while it would not be in the absence of those obstacles, allocating in this way resources from the high productive firms to the low productive ones. We should notice that in cases where the quadratic term is missing is due to statistical insignificance.

Regarding Egypt we observe that the firm age is positively correlated to the dispersion on output, while firms with female and foreign ownership, and those with international qualification of quality and those who are classified as foreign present a negative coefficient. In the second column we show that female ownership is again positively associated with the dispersion on capital, while the coefficient on the exporting firms becomes significant and positive. Firm size and age present a quadratic relationship with $M W$ and $M B$, and specifically an U-curve and an inverse U-curve respectively. In other words, the allocation efficiency is reduced with increases in firm size up to some point and this turning point is estimated at 36 full-time permanent employees for both $M B$ and $M W$ measure. Thus, firms with a number of workers less than 36 are less efficient. On the contrary, the age presents an inverse relationship, where at some point the efficiency is positive and then is declining at 27 years of operation. Thus, firms operating less than 27 years are more efficient. As before firms with female owners perform better, but being part of another firm and exporting reduce the efficiency.

In Turkey we observe that firm size is insignificant, while firm age has a negative effect on allocation efficiency. Firms with at least one female employer present higher levels of allocation efficiency, and those having foreign ownership and they have been accredited with an international certification of quality assurance present lower levels of dispersion on capital and output.

In table 7 and the case of Yemen we observe a linear relationship between firm size and the outcomes of interest, while a quadratic association between firm age and the resource misallocation efficiency measures is noted. In particular, firm size increases the dispersion on output and capital, while age initially reduces the dispersions, but after 22-25 years of operation, the dispersions are increased. Being part of another firm increases the allocation efficiency in terms of the WM and MW measures, and is negatively related to dispersion on capital. While female ownership was positively contributing in the allocation efficiency in the sample of the Egyptian and Turkish firms, this does not hold in the firms of Yemen, at least in our sample, where the female ownership is positively correlated with dispersions on capital. However, as we noticed earlier these variables can be endogenous, and also constraints on female entrepreneurship can be highly likely, as we have seen in table 3. Thus, the more productive firms consisting of female owners can be also highly "taxed" by poor SBRs increasing indirectly the 
allocation efficiency. As this we not be further explored because it's out of the current study's main aim, but we suggest it for future research, especially in the MENA region countries.

However, there are major drawbacks in our analysis. First, the sample of the firms is quite small. Second the period examined, and specifically two waves, is very short. Using a longer period and a larger sample of firms, we will be able to investigate the dynamics across firms, industries and time. Third, another constraint is the non-panel structure of our sample, as we have considered both panel and non-panel components. While the advantage of this approach is that we include the full sample, allowing us to examine broader the resource misallocation across firms and industries using a larger sample, the drawback comes from the fact that we do not follow the same firm across time. We suggest for future research to investigate the relationship among allocation efficiency and the determinants explored in this study for separate industries, such as construction, manufacturing, transport, health and education services. Another point of criticism is the production function and the input factors. In particular, we suggest a more flexible function, instead of the Cobb-Douglas, as well as, the inclusion of additional inputs, such as the land and materials. Another point of interest would be to investigate an alternative form of production function and specifically to explore the Lucas "span-of-control" which refers to decreasing returns to scale. However, this could be more relevant to farming business and agriculture industry, while our analysis does not include this sector.

Table 5. Resource Misallocation Regressions in Egypt

\begin{tabular}{|c|c|c|c|c|}
\hline \multicolumn{5}{|l|}{ Panel A: SBR Access to Finance } \\
\hline $\begin{array}{l}\text { Coefficients } \\
\text { Conel A. SBR Access to }\end{array}$ & $\begin{array}{c}\text { DV: } \\
\operatorname{SD}\left(\log \left(\tau_{y}\right)\right)\end{array}$ & $\begin{array}{c}\text { DV: } \\
\operatorname{SD}\left(\log \left(\tau_{\mathrm{k}}\right)\right)\end{array}$ & DV: MW & DV: MB \\
\hline \multirow[t]{2}{*}{ Access to Finance } & 0.0122 & $0.0103 *$ & $-0.0007 * * *$ & $-0.0097 * * *$ \\
\hline & $(0.0091)$ & $(0.0057)$ & $(0.0002)$ & $(0.0029)$ \\
\hline \multirow[t]{2}{*}{ Log of Firm Size } & -0.0113 & 0.0011 & $-0.0010 * * *$ & $-0.0143 * * *$ \\
\hline & $(0.0085)$ & $(0.0044)$ & $(0.0002)$ & $(0.0037)$ \\
\hline \multirow[t]{2}{*}{ Log of Firm Size Square } & & & $1.4 \mathrm{e}-0.4 * * *$ & $0.0020 * * *$ \\
\hline & & & $(3.5 e-0.5)$ & $(0.0005)$ \\
\hline \multirow[t]{2}{*}{ Log of Firm Age } & $0.0130 *$ & 0.0140 & $0.0016^{* * *}$ & $0.0225 * * *$ \\
\hline & $(0.0076)$ & $(0.0123)$ & $(4.6 \mathrm{e}-0.4)$ & $(0.0065)$ \\
\hline \multirow[t]{2}{*}{ Log of Firm Age Square } & & & $-2.4 \mathrm{e}-0.4 * * *$ & $-0.0034 * * *$ \\
\hline & & & $(9.0 \mathrm{e}-0.5)$ & $(0.0012)$ \\
\hline \multirow[t]{2}{*}{ Female ownership (Yes) } & -0.0055 & $-0.0528 *$ & $0.0006^{* *}$ & $0.0084 * *$ \\
\hline & $(0.0160)$ & $(0.0277)$ & $(0.0003)$ & $(0.0040)$ \\
\hline \multirow[t]{2}{*}{ Part of a Larger Firm (Yes) } & 0.0173 & -0.0225 & $-4.4 \mathrm{e}-0.4^{*}$ & -0.0061 \\
\hline & $(0.0316)$ & $(0.0496)$ & $(2.3 e-0.4)$ & $(0.0041)$ \\
\hline \multirow[t]{2}{*}{ International Certification of Quality (Yes) } & $-0.0428 *$ & -0.0383 & $4.6 \mathrm{e}-0.4$ & $0.0084 * *$ \\
\hline & $(0.0235)$ & $(0.0633)$ & $(3.0 \mathrm{e}-0.4)$ & $(0.0041)$ \\
\hline \multirow[t]{2}{*}{ Foreign ownership } & $-0.0008 * *$ & -0.0004 & $3.58 \mathrm{e}-06$ & $4.5 \mathrm{e}-05$ \\
\hline & $(0.0003)$ & $(0.0003)$ & $(3.46 \mathrm{e}-06)$ & $(5.3 \mathrm{e}-05)$ \\
\hline \multirow[t]{2}{*}{ Exporter } & $3.51 \mathrm{e}-04$ & $7.0 \mathrm{e}-04 *$ & $-1.0 \mathrm{e}-05 * * *$ & $-1.5 \mathrm{e}-0.4 * * *$ \\
\hline & $(2.5 \mathrm{e}-04)$ & $(3.7 \mathrm{e}-04)$ & $(3.51 \mathrm{e}-06)$ & $(5 e-0.5)$ \\
\hline No. observations & 2,712 & 2,720 & 2,770 & 2,770 \\
\hline R-Squared & 0.7667 & 0.8034 & 0.6965 & 0.6965 \\
\hline \multicolumn{5}{|l|}{ Panel B: SBR Political Instability } \\
\hline \multirow[t]{2}{*}{ Political Instability } & 0.0155 & $0.0071 *$ & $-5.2 \mathrm{e}-04 * *$ & $-0.0011 *$ \\
\hline & $(0.0116)$ & $(0.0036)$ & $(2.1 \mathrm{e}-04)$ & $(0.0006)$ \\
\hline No. observations & 2,714 & 2,725 & 2,775 & 2,775 \\
\hline R-Squared & 0.6941 & 0.7898 & 0.6914 & 0.6914 \\
\hline
\end{tabular}




\begin{tabular}{ccccc}
\hline Panel C: SBR Electricity & & & \\
Electricity & $0.0398 * *$ & 0.0306 & $-0.0017 * * *$ & $-0.0176^{* * *}$ \\
& $(0.0192)$ & $(0.0196)$ & $(0.0002)$ & $(0.0033)$ \\
No. observations & 2,754 & 2,762 & 2,783 & 2,783 \\
R-Squared & 0.6975 & 0.7875 & 0.7048 & 0.7048 \\
\hline
\end{tabular}

Standard errors within brackets, p-values within square brackets, $* * *, * *$ and $*$ indicate significance at $1 \%, 5 \%$ and $10 \%$ level.

Table 6. Resource Misallocation Regressions in Turkey

\begin{tabular}{|c|c|c|c|c|}
\hline \multicolumn{5}{|l|}{ Panel A: SBR Access to Finance } \\
\hline Coefficients & DV: $\operatorname{SD}\left(\log \left(\tau_{\mathrm{y}}\right)\right)$ & DV: $\operatorname{SD}\left(\log \left(\tau_{k}\right)\right)$ & DV: MW & DV: MB \\
\hline \multirow[t]{2}{*}{ Access to Finance } & $0.0078^{*}$ & 0.0067 & $-0.0195 * *$ & $-0.0132 * *$ \\
\hline & $(0.0041)$ & $(0.0049)$ & $(0.0088)$ & $(0.0059)$ \\
\hline \multirow[t]{2}{*}{ Log of Firm Size } & 0.1949 & $0.3562 *$ & -0.0010 & -0.0007 \\
\hline & $(0.1518)$ & $(0.1869)$ & $(0.0031)$ & $(0.0021)$ \\
\hline \multirow[t]{2}{*}{ Log of Firm Age } & $0.3163 *$ & 0.4015 & $-0.0118 * * *$ & $-0.008 * * *$ \\
\hline & $(0.1729)$ & $(0.3266)$ & $(0.0036)$ & $(0.0024)$ \\
\hline \multirow[t]{2}{*}{ Female ownership (Yes) } & -0.4690 & -0.4693 & $0.0119 * *$ & $0.0081 * *$ \\
\hline & $(0.4149)$ & $(0.3858)$ & $(0.0057)$ & $(0.0038)$ \\
\hline \multirow[t]{2}{*}{ Part of a Larger Firm (Yes) } & 0.1112 & 0.4826 & 0.0111 & 0.0075 \\
\hline & $(0.6238)$ & $(0.5836)$ & $(0.0082)$ & $(0.0056)$ \\
\hline International Certification of Quality & $-0.2548 *$ & -0.4204 & 0.0021 & 0.0014 \\
\hline$($ Yes $)$ & $(0.1398)$ & $(0.2695)$ & $(0.0058)$ & $(0.0039)$ \\
\hline \multirow[t]{2}{*}{ Foreign ownership } & $-0.0225 * *$ & $-0.0468 * *$ & $1.2 \mathrm{e}-05$ & $8.76 \mathrm{e}-05$ \\
\hline & $(0.0106)$ & $(0.0215)$ & $(1.4 \mathrm{e}-05$ & $(7.5 e-05)$ \\
\hline \multirow[t]{2}{*}{ Exporter } & 0.0037 & 0.0028 & $6.2 \mathrm{e}-05$ & $4.3 e-05$ \\
\hline & $(0.0043)$ & $(0.0059)$ & $(5.7 e-05)$ & $(4.3 e-05)$ \\
\hline No. observations & 1,513 & 1,530 & 2,143 & 2,143 \\
\hline R-Squared & 0.8785 & 0.8344 & 0.7931 & 0.7931 \\
\hline \multicolumn{5}{|l|}{ Panel B: SBR Political Instability } \\
\hline \multirow[t]{2}{*}{ Political Instability } & $0.0481 * *$ & 0.0624 & $-0.0401 * * *$ & $-0.0271 * * *$ \\
\hline & $(0.0217)$ & $(0.0611)$ & $(0.0078)$ & $(0.0053)$ \\
\hline No. observations & 1,501 & 1,527 & 2,138 & 2,138 \\
\hline R-Squared & 0.8780 & 0.8320 & 0.8052 & 0.8052 \\
\hline \multicolumn{5}{|l|}{ Panel C: SBR Tax Rates } \\
\hline \multirow[t]{2}{*}{ Tax Rates } & $0.0046^{*}$ & 0.0057 & $-0.0197 * * *$ & $-0.0133 * * *$ \\
\hline & $(0.0025)$ & $(0.0049)$ & $(0.0069)$ & $(0.0046)$ \\
\hline No. observations & 1,495 & 1,522 & 2,154 & 2,154 \\
\hline R-Squared & 0.8783 & 0.8342 & 0.7942 & 0.7942 \\
\hline
\end{tabular}

Standard errors within brackets, p-values within square brackets, ***,** and * indicate significance at $1 \%, 5 \%$ and $10 \%$ level.

Table 7. Resource Misallocation Regressions in Yemen

\begin{tabular}{|c|c|c|c|c|}
\hline \multicolumn{5}{|l|}{ Panel A: SBR Corruption } \\
\hline Coefficients & DV: $\operatorname{SD}\left(\log \left(\tau_{\mathrm{y}}\right)\right)$ & $D V: \operatorname{SD}\left(\log \left(\tau_{k}\right)\right)$ & DV: MW & DV: MB \\
\hline Corruption & $\begin{array}{c}0.5777 * * * \\
(0.1802)\end{array}$ & $\begin{array}{c}0.2364 * * \\
(0.0902)\end{array}$ & $\begin{array}{c}-0.0186 * * * \\
(0.0009)\end{array}$ & $\begin{array}{c}-0.0040 * * * \\
(0.0006)\end{array}$ \\
\hline Log of Firm Size & $\begin{array}{c}0.6334 * * * \\
(0.1798)\end{array}$ & $\begin{array}{c}0.3970 * * * \\
(0.0939)\end{array}$ & $\begin{array}{c}0.0038 \\
(0.0025)\end{array}$ & $\begin{array}{c}0.0002 \\
(0.0004)\end{array}$ \\
\hline Log of Firm Age & $\begin{array}{c}-1.9548 * * \\
(0.9091)\end{array}$ & $\begin{array}{c}-1.145 * * * \\
(0.3822)\end{array}$ & $\begin{array}{c}-0.0369 * * * \\
(0.0066)\end{array}$ & $\begin{array}{c}-0.0026 * * * \\
(0.0004)\end{array}$ \\
\hline Log of Firm Age Square & $\begin{array}{l}0.3131 * \\
(0.1887)\end{array}$ & $\begin{array}{l}0.1810 * * \\
(0.0696)\end{array}$ & & \\
\hline Female ownership (Yes) & $\begin{array}{c}0.9795 \\
(0.4442)\end{array}$ & $\begin{array}{c}0.4216^{* *} \\
(0.2185)\end{array}$ & $\begin{array}{c}0.0058 \\
(0.0174)\end{array}$ & $\begin{array}{c}0.0040 \\
(0.0121)\end{array}$ \\
\hline
\end{tabular}




\begin{tabular}{|c|c|c|c|c|}
\hline Part of a Larger Firm (Yes) & $\begin{array}{l}-0.2021 \\
(0.2653)\end{array}$ & $\begin{array}{c}-0.2453^{* *} \\
(0.1197)\end{array}$ & $\begin{array}{c}0.0624 * * * \\
(0.0101)\end{array}$ & $\begin{array}{c}0.0043 * * * \\
(0.0007)\end{array}$ \\
\hline \multirow[t]{2}{*}{ International Certification of Quality (Yes) } & -0.1845 & -0.1030 & 0.0050 & -0.0004 \\
\hline & $(0.3955)$ & $(0.1589)$ & $(0.0179)$ & $(0.0127)$ \\
\hline \multirow[t]{2}{*}{ Foreign ownership } & -0.0051 & -0.0010 & $1.7 \mathrm{e}-04$ & $1.2 \mathrm{e}-05$ \\
\hline & $(0.0069)$ & $(0.0028)$ & $(2.0 \mathrm{e}-04)$ & $(1.1 \mathrm{e}-05)$ \\
\hline \multirow[t]{2}{*}{ Exporter } & 0.0004 & 0.0023 & $2.8 \mathrm{e}-05$ & $1.94 \mathrm{e}-06$ \\
\hline & $(0.0003)$ & $(0.0018)$ & $(2.1 \mathrm{e}-05)$ & $(1.4 \mathrm{e}-05)$ \\
\hline No. observations & 602 & 628 & 758 & 758 \\
\hline R-Squared & 0.7948 & 0.8256 & 0.7798 & 0.7798 \\
\hline \multicolumn{5}{|l|}{ Panel B: SBR Political Instability } \\
\hline \multirow[t]{2}{*}{ Political Instability } & $0.7714 * * *$ & $0.2667 * *$ & $-0.0124 * *$ & $-0.0029 * *$ \\
\hline & $(0.1659)$ & $(0.1110)$ & $(0.0060)$ & $(0.0011)$ \\
\hline No. observations & 600 & 624 & 753 & 753 \\
\hline R-Squared & 0.7895 & 0.8262 & 0.4564 & 0.4564 \\
\hline \multicolumn{5}{|l|}{ Panel C: SBR Electricity } \\
\hline \multirow[t]{2}{*}{ Electricity } & 0.2721 & 0.1576 & $-0.0135 * *$ & $-0.0020 * *$ \\
\hline & $(0.2259)$ & $(0.0984)$ & $(0.0062)$ & $(0.0008)$ \\
\hline No. observations & 608 & 632 & 766 & 766 \\
\hline R-Squared & 0.7816 & 0.8306 & 0.4461 & 0.4461 \\
\hline
\end{tabular}

Standard errors within brackets, p-values within square brackets, $* * *, * *$ and $*$ indicate significance at $1 \%, 5 \%$ and $10 \%$ level.

\section{Conclusions}

This study tried to measure the resource misallocation in Egypt, Turkey and Yemen, and to evaluate the relationship between allocation efficiency and major obstacles in SBRs along with other factors. Our results have shown that severe and major obstacles related to specific SBRs expressed by the access to finance, political instability, electricity, corruption and tax rates are the most important factors to allocation efficiency and resource misallocation. The main findings have policy implications and they offer useful insights, as policy makers should provide a reliable infrastructure of electricity, and give incentives in terms of lower tax rates or favourable tax credits to firms that can be highly productive, such as firms with high-skilled employees and technology, and those using energy efficient sources. Also, policy makers should first and foremost shield the economy against corruption and destabilizing political events. Following the Arab spring revolution and the latest political events in Turkey, policy makers should focus on reducing political instability and corruption in regions that were the most affected, reducing inequalities in unemployment and wealth, but also to encourage female entrepreneurship and to target to support small-medium and exporting firms. 


\section{References}

Aga, G., Francis, D.C. and Meza, J.R. (2015). SMEs, Age, and Jobs A Review of the Literature, Metrics, and Evidence. World Bank Policy Research Working Paper 7493. Development Economics, Global Indicators Group.

Aga, G. and Francis, D.C. (2017). As the market churns: productivity and firm exit in developing countries. Small Business Economics, 49(2), 379-403

Asker, J., Collard-Wexler, A. and De Loecker, J. (2014). Dynamic Inputs and Resource (Mis)Allocation. Journal of Political Economy, 122(5), 1013-1063.

Baldwin, J. and Yan, B. (2011). The death of Canadian manufacturing plants: heterogeneous responses to changes in tariffs and real exchange rates. Review of World Economics, 147(1), 131-167.

Bartelsman, E., Haltiwanger, J. and Scarpetta, S. (2013). Cross-Country Differences in Productivity: The Role of Allocation and Selection. American Economic Review, 103(1), 305-334.

Beck, T., Demirguc-Kunt, A. and Maksimovic, V. (2005). Financial and Legal Constraints to Growth: Does Firm Size Matter? The Journal of Finance, 60(1), 137-177.

Beck, T. and Demirguc-Kunt, A. (2006) Small and medium-size enterprises: Access to finance as a growth constraint. Journal of Banking and Finance, 30, 2931-2943.

Bernard, A. and Sjöholm, F. (2003). Foreign Owners and Plant Survival. NBER Working Papers 10039.

Biesebroeck, J.V. (2005). Firm size matters: Growth and productivity growth in African manufacturing. Economic Development and Cultural Change, 53(3), 545-583.

Brandt, L., Tombe, T. and Zhu, X. (2013). Factor Market Distortions Across Time, Space, and Sectors in China. Review of Economic Dynamics, 16(1), 39-58.

Busso, M., Madrigal, L. and Pagés, C. (2013). Productivity and Resource Misallocation in Latin America. B.E. Journal of Macroeconomics, 13 (1), 903-932.

Caballero, R.J., Hoshi, T. and Kashyap, A.K. (2008). Zombie Lending and Depressed Restructuring in Japan. American Economic Review, 98(5), 1943-1977.

Caggese, A. and Cuñat, V. (2013). Financing constraints, firm dynamics, export decisions, and aggregate productivity. Review of Economic Dynamics, 16(1), 177-193.

Carlin, W., Schaffer, M., Seabright, P. (2006). Where are the Real Bottle necks? A Lagrangian Approach to Identifying Constraints on Growth from Subjective Data, CERT Discussion Paper 2006/04. Centre for Economic Reform and Transformation, School of Management and Languages, Heriot-Watt University, Edinburgh.

Chuah, L.L., Loayza, N.V. and Nguyen, H. (2018). Resource Misallocation and Productivity Gaps in Malaysia. Policy. Research Working Paper 8368. Development Research Group, Macroeconomics and Growth Team

Cirera, X., Jaef, R.N.F. and Maemir, H.B. (2017). Taxing the Good? Distortions, Misallocation, and Productivity in Sub-Saharan Africa. Policy Research Working Paper 7949, World Bank Group, Trade and Competitiveness Global Practice Group \& Development Research Group.

Collier, P. and Duponchel, M. (2013). The Economic Legacy of Civil War: Firm-level Evidence from Sierra Leone. Journal of Conflict Resolution, 57(1), 65-88 
Coolidge, J. (2012). Findings of tax compliance cost surveys in developing countries. eJournal of Tax Research, 10(2), 250-287

Croson, R. and Gneezy, U. (2009). Gender differences in preferences. Journal of Economic Literature, 47(2), 448-474.

Diaz, M.A. and Sanchez, R. (2008). Firm size and productivity in Spain: A stochastic frontier analysis. Small Business Economics, 30(3), 315-323

Epifani, P. and Gancia, G. (2011). Trade, Markup, Heterogeneity and Misallocations. Journal of International Economics, 83(1), 1-13.

Eslava, M., Haltiwanger, J. C., Kugler, A. and Kugler, M. (2013). Trade Reforms and Market Selection: Evidence from Manufacturing Plants in Colombia. Review of Economic Dynamics, 16(1), 135-158.

Evans, C., Lignier, P. and Tran-Nam, B. (2013). Tax Compliance Costs for The Small and Medium Enterprise Business Sector: Recent Evidence from Australia. Discussion Paper 03-13, Exeter: Tax Administration Research Centre

Faccio,M., Marchica, M. T. and Mura, R. (2016). CEO gender and corporate risk-taking. Journal of Corporate Finance, 39, 193-209.

Gelübcke, J. and Wagner, J. (2012). Foreign ownership and firm survival: first evidence for enterprises in Germany. Economie Internationale, 132, 117-139.

Gopinath, G., Kalemli-Ozcan, S., Karabarbounis, L. and Villegas-Sanchez, C. (2015). Capital Allocation and Productivity in South Europe. NBER Working Paper No 21453.

Guner, N., Ventura, G. and Xu, Y. (2008). Macroeconomic implications of size-dependent policies. Review of Economic Dynamics, 11(4), 721-744.

Harhoff, D., Stahl, K. and Woywode, M. (1998). Legal form, growth and exit of West German firms. Journal of Industrial Economics, 46, 453-488.

Hopenhayn, H. and Rogerson, R. (1993). Job Turnover and Policy Evaluation: A General Equilibrium Analysis. Journal of Political Economy, 101(5), 915-938.

Hsieh, C. and Klenow, P. (2009). Misallocation and manufacturing TFP in China and India. Quarterly Journal of Economics, 124(4), 1403-1448.

Hsieh, C., Hurst, E., Jones, C. I. and Klenow, P. (2013). The allocation of talent and us economic growth. NBER Working Paper No. w18693.

Kingombe, C. and te Velde,D. W. (2016). The Role of Special Economic Zones in Manufacturing

Lagos, R. (2006). A Model of TFP. Review of Economic Studies, 73(4), 983-1007.

Lawless, M. (2014). Age or size? Contributions to job creation. Small Business Economics, 42(4), 815830.

Lea, N. and Hanmer, L. (2009) Constraints to Growth in Malawi. Policy Research Working Paper 5097, Washington DC: The World Bank.

Lemma, A., Massa, I., Scott, A. and te Velde, A.W. (2016). What are the links between power, economic growth and job creation? Development Impact Evaluation, Evidence Review, Overseas Development Institute.

León-Ledesma, M. A., McAdam, P. and Willman, A. (2010). Identifying the Elasticity of Substitution with Biased Technical Change. American Economic Review, 100(4), 1330-1357 
León-Ledesma, M. (2016). Potential Growth, Misallocation, and Institutional Obstacles: Firm-Level Evidence. Asian Development Bank. ADB Economics Working Paper Series.

Lileeva, A. and Trefler, D. (2010). Improved Access to Foreign Markets Raises Plant-Level Productivity...for Some Plants. Quarterly Journal of Economics, 125(3), 1051-1099

Lundvall, K. and Battesse, G.E. (2000). Firm size, age and efficiency: Evidence from Keynesian manufacturing firms. The Journal of Development Studies, 36(3), 146-163

Midrigan, V., Xu, Y. (2014). Finance and misallocation: Evidence from Plant-Level Data. American Economic Review, 104(2), 422-458.

Nguyen, H., Taskin, T. and Yilmaz, A. (2016). Resource Misallocation in Turkey. Policy Research Working Paper 7780. World Bank Group, Development Research Group Macroeconomics and Growth Team \& Macroeconomics and Fiscal Management Global Practice Group.

Oberfield, E. (2013). Productivity and misallocation during a crisis: Evidence from the Chilean crisis of 1982. Review of Economic Dynamics, 16, 100-119.

Restuccia, D. and Rogerson, R. (2008). Policy Distortions and Aggregate Productivity with Heterogeneous Establishments. Review of Economic Dynamics, 11(4), 707-720.

Schiffer, M. and Weder, B. (2001). Firm size and the business environment: Worldwide survey results. International Finance Corporation: Discussion Paper 43

Slemrod, J and Venkatesh, V. (2002). The income tax compliance cost of large and mid-size businesses. Office of Tax Policy Research, University of Michigan Business School. University of Michigan Business School.

World Bank (2008). Kenya: Accelerating and Sustaining Inclusive Growth. Report No. 42844-KE, Washington DC 